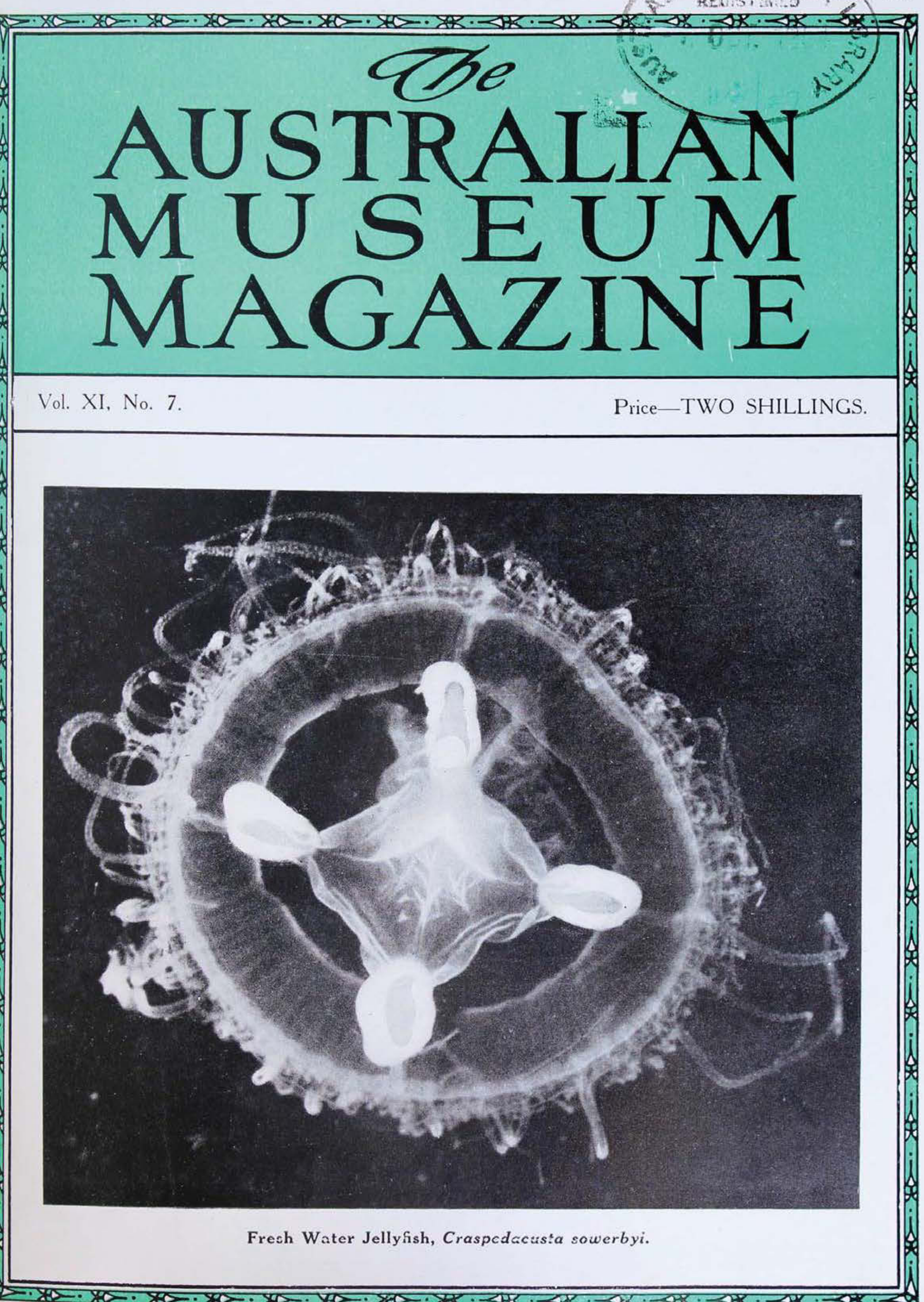




\section{THE AUSTRALIAN MUSEUM}

HYDE PARK, SYDNEY

\section{B OARD OF TRUSTEES \\ PIESIDENT :}

H. B. MATHEWS, B.A.

CROWN TRUSTEE:

H. B. MATHEWS, B.A.

OFFICIAL TRUSTEES :

THE HON. THE CHIEF JUSTICE.

THE HON. THE PRESIDENT OF THE LEGISLATIVE COUNCIL. THE HON. THE COLONIAL SECRETARY.

THE HON. THE ATTORNEY GENERAL.

THE HON. THE COLONIAL TREASURER.

THE HON. THE SECRETARY FOR PUBLIC WORKS,

THE HON. THE MINISTER OF PUBLIC INSTRUCTION. THE AUDITOR-GENERAL.

THE PRESIDENT OF THE NEW SOUTH WALES MEDICAL BOARD. THE SURVEYOR-GENERAL AND CHIEF SURVEYOR. THE CROWN SOLICITOR.

\section{ELECTIVE TRUSTEES :}

PROF. A. N. St. G. BURKITT, M.B., B.Sc. FRANK B. SPENCER.

O. G. VICKERY, B.E., M.I.E. (Aust.). WALLACE C. WURTH, C.M.G., LL.B. PROF. A. P. ELKIN, M.A., Ph.D. F. MCDOWELL.
R. J. NOBLE, M.Sc,, B.Sc.Agr., Ph.D.

E. J. KENNY, M.Aust. I.M.M.

F. L. S. BELL, M.A., F.R.A.I.

FRANK W. HILL.

G. A. JOHNSON.

PROF. P. D. F. MURRAY, M.A., D.Sc.

\section{DIRECTOR :}

A. B. WALKOM, D.Se.

Assistant to the Director:

J. R. KINGHORN, C.M.Z.S

\section{SCIENTIFIC STAFF :}

Birds, Reptiles and Amphibians: J. R. KINGHORN, C.M.Z.S., Curator; J. A. KEAST, M.Sc., Assistant Curator.

Mammals and Skeletons: E. Le G. TROUGHTON, F.R.Z.S., C.M.Z.S., Curator.

Fishes: G. P. WHITLEY, F.R.Z.S., Curator.

Insects and Arachnids: A. MUSGRAVE, F.R.Z.S., F.R.E.S., Curator.

Molluses: JOYCE ALLAN, F.R.Z.S., Curator; D. F, McMICHAEL, M.A., B.Sc., Assistant Curator.

Crustacea and Other Groups : F. A. McNEILL, Curator ; ELIZABETH C. POPE, M.Sc., C.M.Z.S., Assistant Curator.

Minerals and Rocks: R. O. CHALMERS, A.S.T.C., Curator; J. F. LOVERING, M.Sc., Assistant Curator. Fossils: H. O. FLETCHER, Curator.

Anthropology: F. D. McCARTHY, Dip.Anthr., Curator.

\section{LIBRARY AND PUBLICATIONS: \\ MARGARET W. FRASER. \\ DEPARTMENT OF PREPARATION : \\ J. KINGSLEY.}

Zoologists.

Asst. Prof. E. A. BRIGGS, D.Sc.

H. LEIGHTON KESTEVEN, D.Sc., M.D

MELBOURNE, WARD, F.R.Z.S., F.Z.S

TOM IREDALE.

Entomologist.

T. H. GUTHRIE.

\section{HONORARY SCIENTIFIC STAFF :}

Ornithologist.

K. A. HINDWOOD, C.F.A.O.U., F.R.Z.S,

Archaeologist.

Prof. J. L SHEllshear, M.B., Ch.M

Numismatist.

G. C. HEYDE, A.S.T.C., F.R.N.S

Philatelist.

FRANK W. HILL. 


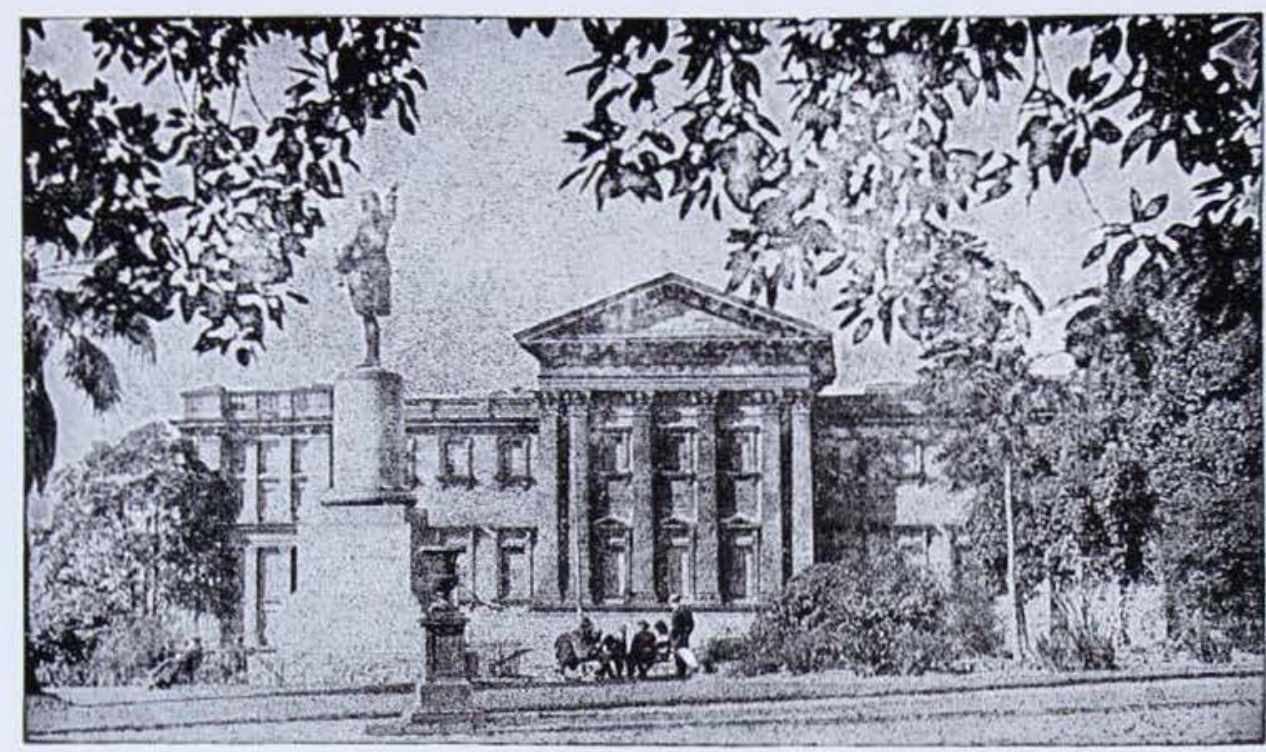

\section{THE AUSTRALIAN MUSEUM MAGAZINE}

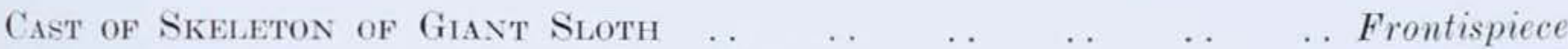

$\begin{array}{lllllllllll}\text { Apponntant of Dr. J. W. Evins } & \ldots & \ldots & \ldots & \ldots & \ldots & \ldots & 207\end{array}$

Pouname and Tangiwat: The Greenstone of New Zeiland (Part II) -

$\begin{array}{llllllllll}\text { Frederick D. McCarthy } & \text {. } & \ldots & \ldots & \ldots & \ldots & \ldots & \ldots & \ldots & \\ 208\end{array}$

A Man and a Museum : Sir Hixs Sloane, Birt.-Joyce Allan . $\quad$. 215

"Fice Lift" for Museum's Giant Sloth-H. O. Fletcher _ . . . . 218

Fossm. Remains from Wombeyan Caves $\quad \ldots \quad$.

Photography in the Field : Hints on Equipment for the Nituralist$\begin{array}{llllllllll}\text { Howard Hughes } & \ldots & \ldots & \ldots & \ldots & \ldots & \ldots & \ldots & \ldots & \\ 2\end{array}$

An Elusive Jellyfish from Fresh Water-Frank McNeill . . . . 225

Tasmania's West Co.sst Mineral Localities: I. Mount Lyele- $R$. $O$.

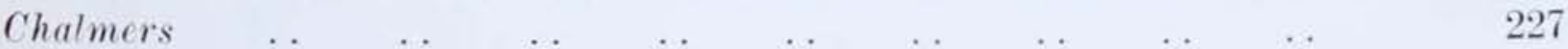

Insects of Captain Cook's Expedition (PaRT I) - A. Musgrave . . . 232

$\begin{array}{lllllllllllll}\text { Воок Reviews } & \ldots & \ldots & \ldots & \ldots & \ldots & \ldots & \ldots & \ldots & \ldots & 237\end{array}$

(Photography, unless otherwise stated, is by Howard Hughes, A.R.P.S.)

- OUR FRONT COVER shows a dorsal view (much enlarged) of a tiny jellyfish, Craspedacusta sowerbyi. Additional illustrations appear on Pages 225 and 226 in an article deseribing the chance discovery of this interesting species in a water sample from a Sydney reservoir.

VOLLME XI, NUMBER 7. 


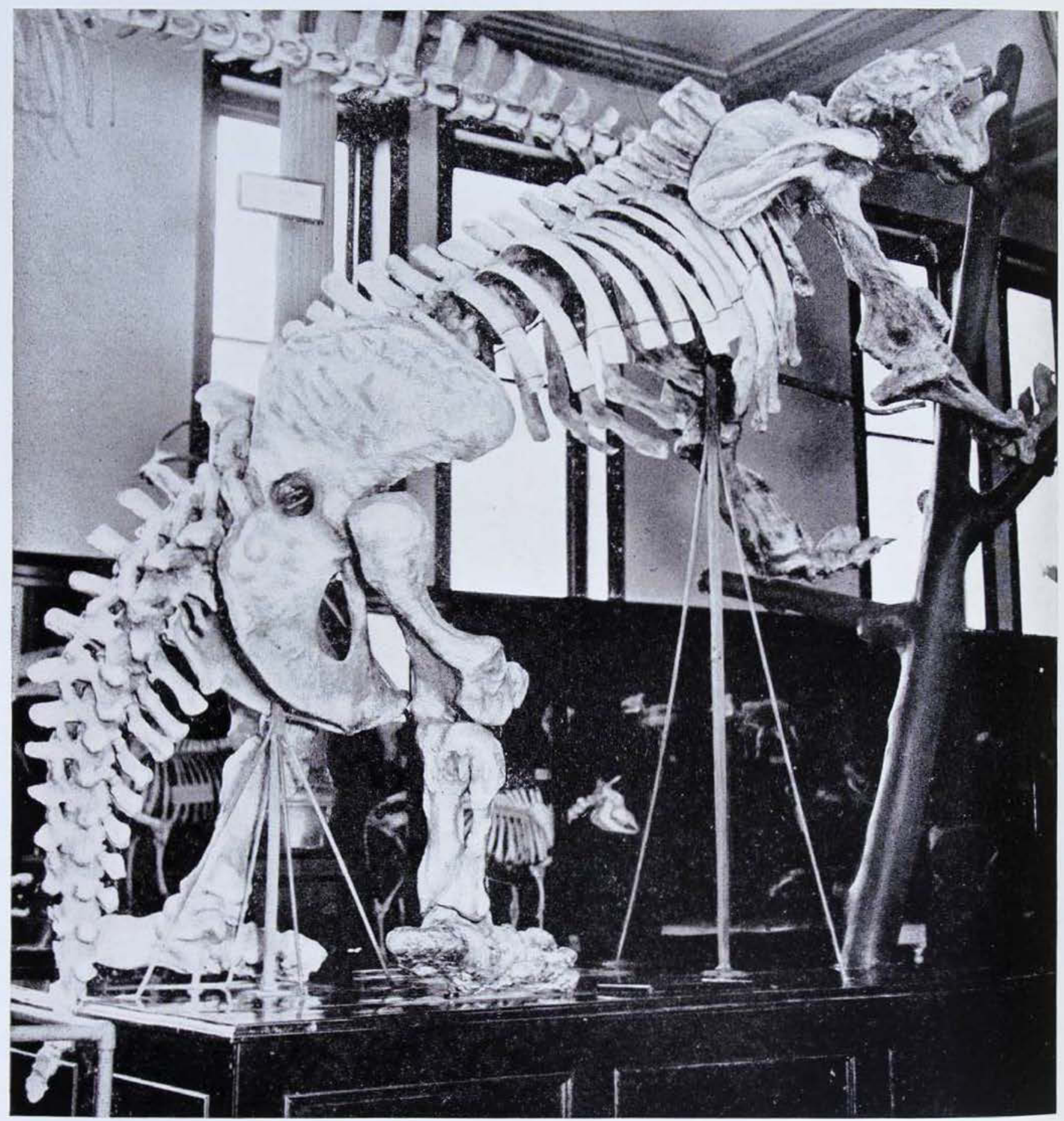

Cast of a skeleton of the Giant Sloth of South America, in the Australian Museum. It represents an animal about eighteen feet in length and reveals the massive bones of the hindquarters. (See article on page 218.) Part of a skeleton of a Beaked Whale appears in the top left corner of the picture. 


\section{THE A USTR L I A N MUSEUM MAGAZINE}

Published by the Austratian Museum

College Street, Sydney Editor: A. B. Walkom, D.Sc.

Annual Subscription, Post Free, $8 / 6$

VoL. XI, No. 7.

SEPT. 15,1954

\section{Appointment of Dr. J. W. Evans as Director of the Museum}

$\mathrm{D}$ R. JOHN WILLIAM EVANS, Deputy Chief Scientific Officer of the United Kingdom Civil Service, has been appointed Director of the Australian Museum to succeed the present Director, Dr. A. B. Walkom. Dr. Evans graduated B.A. at Cambridge in 1926 and took his M.A. in 1931. He was awarded the degree of D.Sc. by the University of Tasmania in 1939, and Sc.D. by the University of Cambridge in 1949.

After graduating at Cambridge he came to Australia in 1926 and joined the staff of the Council for Scientific and Industrial Research. In 1927 on the recommendation of Professor S. M. Wadham he was awarded a Science and Industry Endowment Fund Studentship for training in Applied Entomology, to study at the Cawthron Institute, Nelson, N.Z., under the late Dr. R. J. Tillyard. In 1928 he visited entomological research laboratories in Canada and the United States, and in 1928-29 worked under Dr. W. R. Thompson, in the parasite laboratory of the Imperial Institute of Entomology at Farnham Royal, England. From 1929 to 1934 he was Entomologist in the Council for Scientific and Industrial Research, working at the Plant Research Laboratory, Melbourne, the Waite Agricultural Research Institute, Adelaide, and

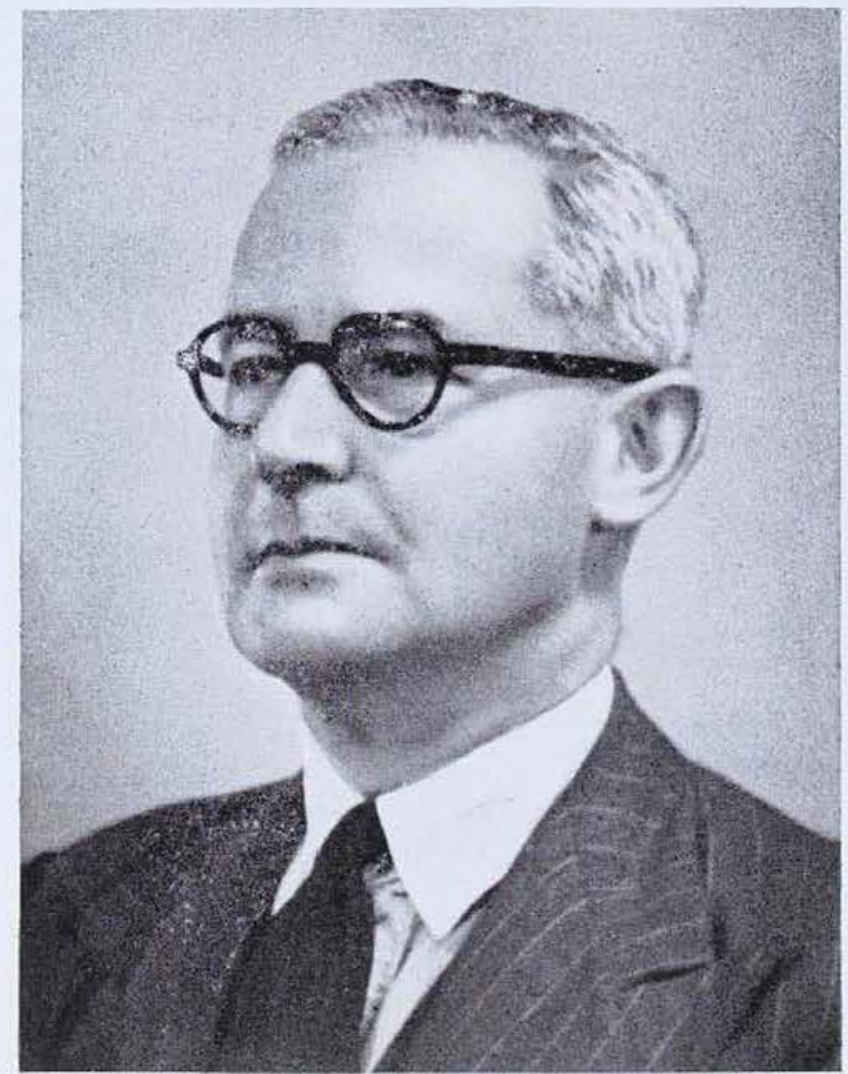

Dr. J. W. Evans.

the headquarters of the Council at Canberra. In 1934 he spent three months in England visiting research laboratories and the British Museum. In 1935 he was appointed Entomologist to the Department of Agriculture, Hobart, and at a lates date was given administrative charge of the entomological and plant pathological sections of the Department, with the title 
Chief Biologist. While he was in Tasmania he was a member of the University Council, the State Committee of C.S.I.R., and the National Park Board, a councillor of the Royal Society of Tasmania, and a Trustee of the Tasmanian Museum. In 1944 he went to London as Senior Entomologist of the Commonwealth Institute of Entomo$\log y$, and spent five years working at the British Museum. From 1948 to 1952 he was Assistant Director of the Infestation Control Division of the Ministry of Agrieulture and Fisheries, and in 1952 was appointed to his present position. In England he took an active part in the work of scientific bodies, serving on the Councils of the Institute of Biology, the Biological Council, the Royal Entomological Society, the Ray Society, the Systematics Association and the Association of Applied Biologists. He was also a member of the Home Office Wild Birds Protection Advisory Committee, and the Colonial Office Research Sub-Committee.

Dr. Evans has had a wide scientific and administrative experience, and has visited Museums in the United States, India, France, Holland, Sweden and Germany, as well as in the Lnited Kingdom. Though his employment has been mainly as an applied entomologist his interests, as shown by his forty or so papers published in scientific journals, have been chiefly in the realm of taxonomy, comparative morpho$\log y$ and ecology. Dr. Evans is due to arrive in sydney early in November.

\section{Pounamu and Tangiwai: the Greenstone of New Zealand}

Part II

By FREDERICK D. McCARTHY.

The Uses of Greenstone.

Pounamu greenstone provided excellent material for the wide range of weapons, implements and ornaments for which it was used by the Maoris of New Zealand.

Among the weapons the mere is the best known. Originally it was made of whalebone, and frequently of basalt and other rocks, but during the past few centuries pounamu became the most favoured material. Meres vary from about twelve to twenty inches in length as a rule, and were thrust through the belt when earried. In use, the thong of dogskin (secured to the butt through a hole) was passed round the thumb and hand in a running noose that could be released were the weapon grasped by an opponent. It is a close combat weapon, used principally to finish off a man in combat. His hair was held and the sharp end of the mere thrust through his temporal bone into the brain. A second blow was sometimes struck downwards on the skull with the thick butt. The blade was not swung clubwise because of the danger of its being broken. Meres are the most highly valued possessions of Maori ehiefs, who, in war, preferred to be killed with their own mere rather than with that of an enemy. Two hundred and fifty eaptives were claimed to have been slain at one time, each with a single blow, with a mere belonging to the chief Te Wherowhero. This mere was inherited by his son Te Rehi.

The killing axe (toki pou tangata) is a beautifully fashioned weapon - a long, thin blade made of specially selected stone, 


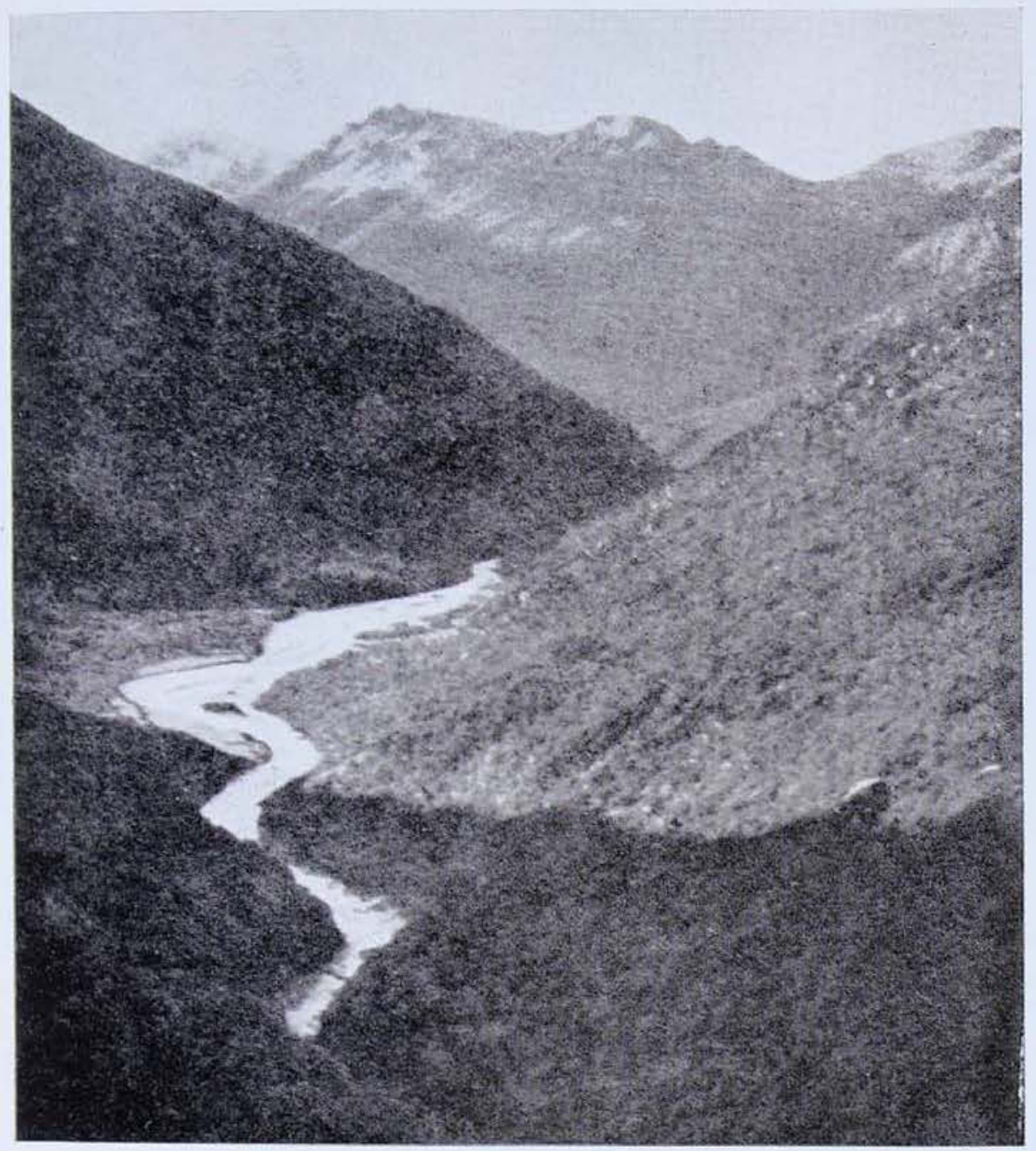

The Arahura Valley, Westland, New Zealand, one of the goals of Maoris searching for greenstone. Photo.-. D. Pascoe in
"Making New Zealand", Vol. II.

mounted on a carved handle decorated with dog's hair. Such a blade could only be made out of greenstone, and it is a development since the working of pounamu began.

Greenstone adzes and chisels of great variety exist. The adzes include those with quadrangular and "hog-back" sections, both highly advanced Neolithic forms. They are usually between four and ten inches long, but exceptional examples are larger, and weigh up to five pounds. They were not used for heavy, rough work such as felling trees and hoeing gardens, but for wood-carving, shaping boards and posts, and making canoes, wooden utensils and boxes. The chisels may be as small as an inch long and a quarter of an inch wide. They were once worn as pendants, as a symbol of ehiefly rank in some tribes, and this custom is believed to have inspired the
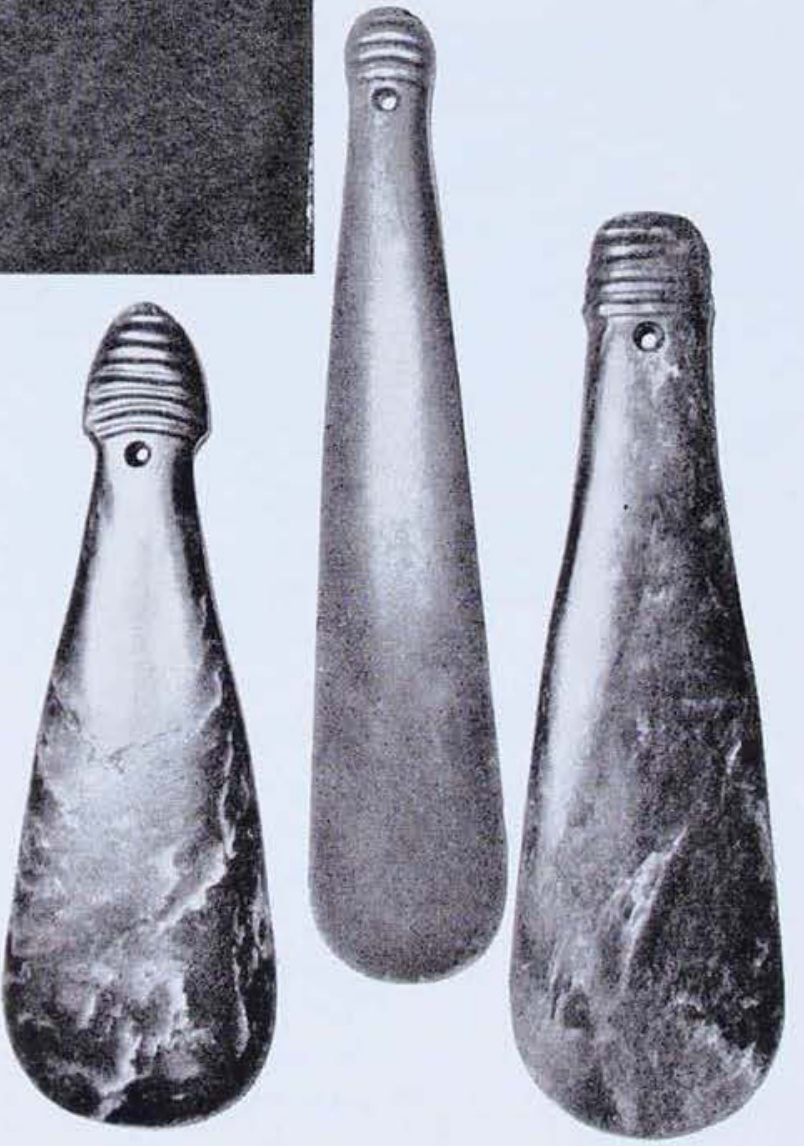

Three greenstone mere-pounamu, 14 to $18 \frac{1}{2}$ inches long, from the Sir William Dixson collection in the Australian Museum. 

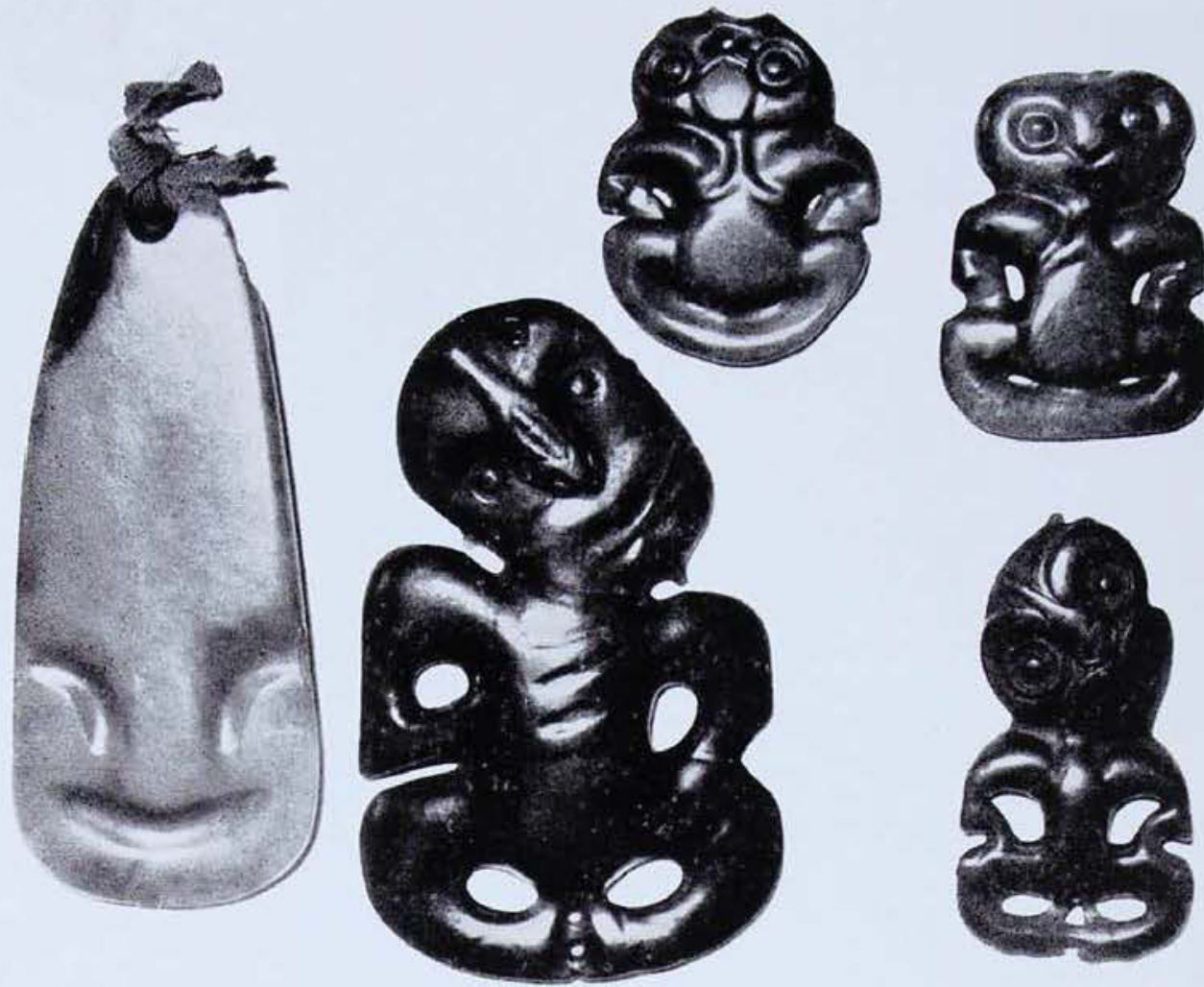

Four hei-tikis of various styles, from $3 \frac{1}{2}$ to 5 inches long, carved from a wide range of pounamu greenstone. The carving of a tiki from the adze on the left is just begun. The two specimens in the lower right are from the Sir William Dixson collection.

production of ear-drops. J. M. MeEwen, after tests, pointed out that any kind of wood-carving can be done with greenstone chisels although it takes more time and the carver has to be content to remove only shallow chips. For this reason it eannot be determined in all cases whether a carving was done with greenstone or with steel tools. Greenstone implements are little short of steel in working qualities. Other implements made of pounamu include slim needles for sewing cloaks, fish-hooks and shanks, flax serapers, cloak toggles, and the head-rest of the Ngati-makuta tribe in the Waikato district.

The pendants provide the greatest variety, but as they are worn chiefly by women, they do not acquire the great mana and sacred value of the mere and some adzes, even though the wearers are of high rank.

The hei-tiki is the most notable of the pendants, and about it there has centred much controversy and conjecture. In shape it is like a compressed human figure of a type common in Maori wood-carvings. The most popular or classical style of heitiki is rectilinear in shape; the head is tilted to one side, and has a figure-of-eight mouth, split tongue, a circular eye denoted by abalone shell or red wax, and a pointed chin. The limbs are curved, and there are decorative incisions on the body. There are three fingers on each hand. Both hands are placed on the stomach or on the legs, or one may be on the head. Tiki is a widespread Polynesian name for the first male created by Tane, carvings of whom are common in stone and bone in the various islands. Hei means "to wear round the neck', According to legend. the first hei-tiki was made for Hinei-taiwaiwa, the goddess of childbirth, by her father in Hawaiki, when the world was peopled by gods.

One interpretation of this pendant is that it represents a phallus, and another one that it is a human foetus. Dr. H. D. skinner, however, has shown that it does 

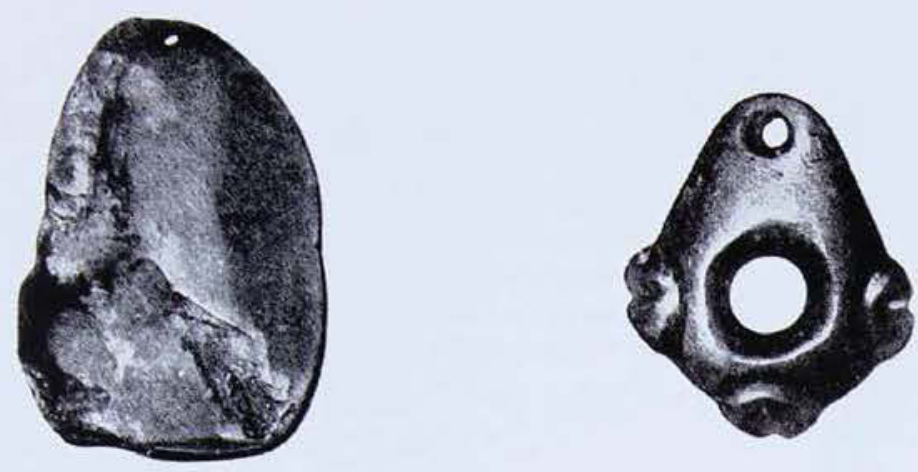

Above: Slightly polished lump of greenstone (whakakia), and a bird-leg ring (kakaporia), 2 inches long.

not resemble a human embryo in anatomical details, and that the large head, perhaps its most typical feature, is also characteristic of Maori wood-carving. As to the three-fingered hands it has been suggested that the deletion of the other fingers alters the representation sufficiently from human form to obviate its use in avenging an insult by magieal purposes. Others believe that this peculiar hand represents the frigate-bird's foot. The late Dr. Buck was of opinion that the hei-tiki incorporates established conventions in wood and bone carving, modified by the character of the stone material and the initial form of the pieces utilized. The shape was developed partly because of the desire to save labour, by retaining the convex edge of the blade of the adze on which the legs are carved.

As a valuable ornament the hei-tiki became an amulet regarded as an embrvo and endowed with the magical power of promoting fertility. All of those bearing sex organs, it is interesting to note, are female. Hei-tikis are from less than two to more than five inches long. Captain Cook said they were worn by both sexes, but such a decoration was normally the privilege of women of rank. Hei-tikis were neither prayed to nor appealed to for assistance. It is generally believed that they are symbols of the origin of mankind from Tiki, and that they were made in bone before the Maori turned to greenstone. Other materials are extremely rare.

All the greenstone pendants illustrated here are from the Sir William Dixson collection in the Museum. Top to bottom: Two pekapeka; a coiled pendant (koropepe); a hei-matau, 3 inches in diameter.
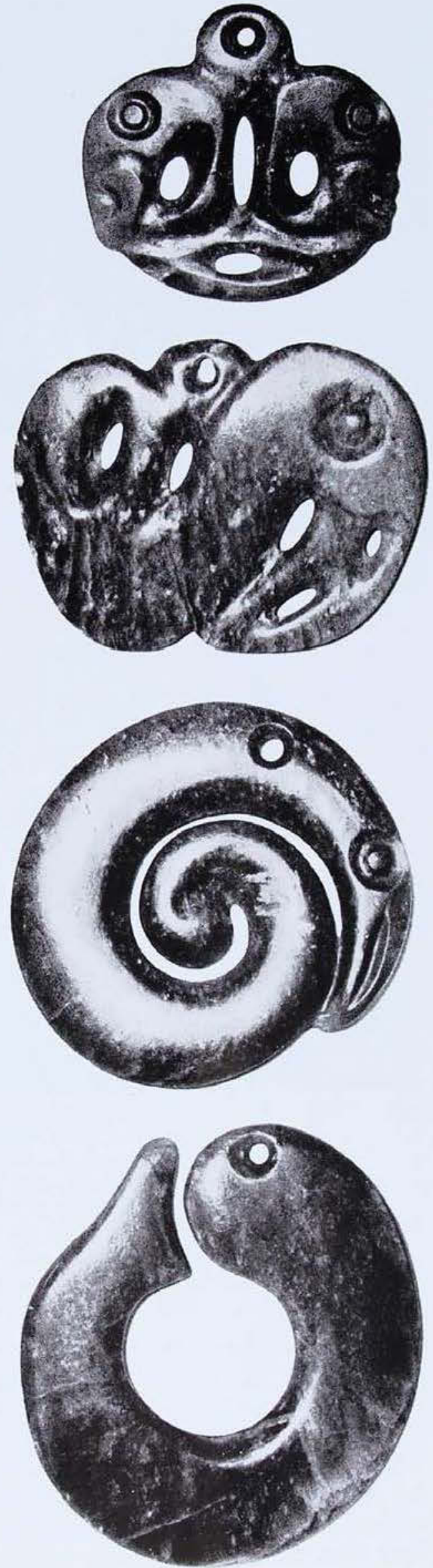


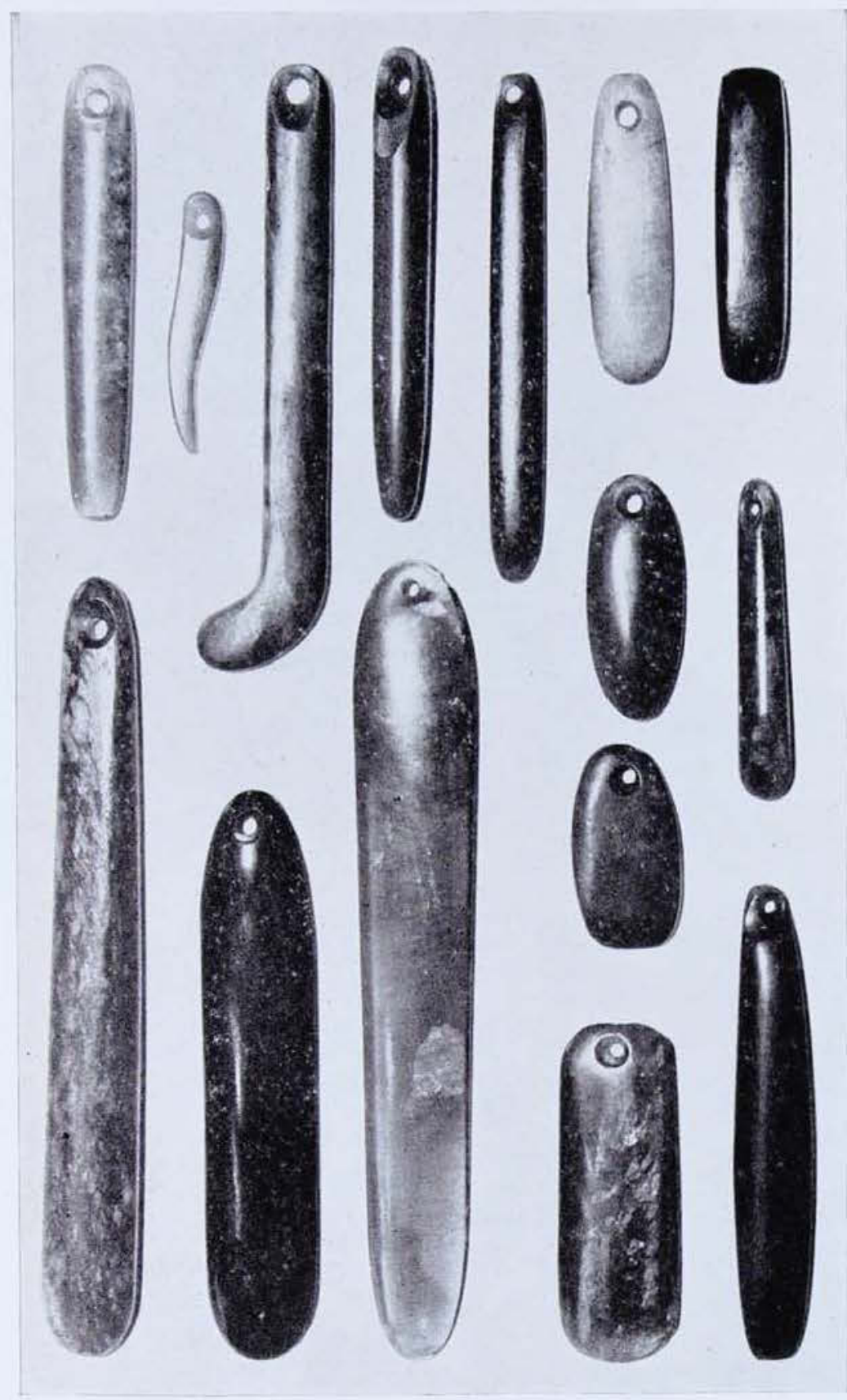

Ear pendants (muru) are greenstone, including tangiwai and pounamu. The tear-drop beauty of tangiwai is well shown in the largest specimen (middle bottom) in this series from the Sir William Dixson collection.

A very beautiful tangiwai greenstone ornament (right), $13 \frac{1}{2}$ inches long, one of the finest of its type known. It has an old Maori two-ply binding on the head, to which is attached a reddish-brown tassel of flax fibres. It is said to have been given to Captain Cook by a Maori chief. It formed part of the John Mackrell collection displayed in the New South Wales court at the Colonial and Indian Exhibition, London,

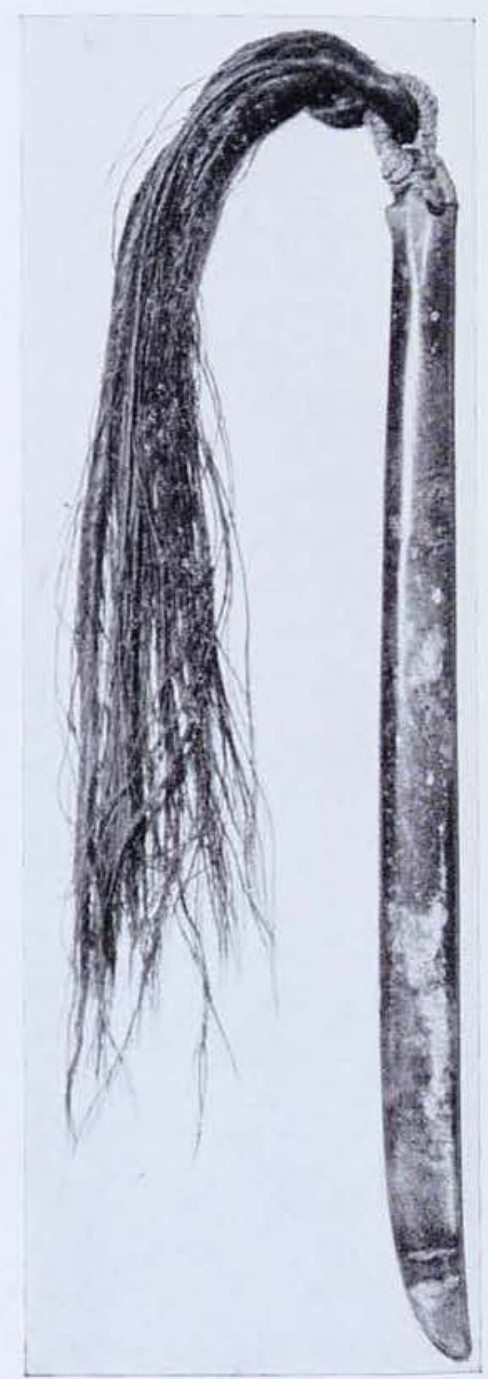
1886 , and is now in the Australian Museum.

It was not known in the Chatham Islands among the Moriori. The carving of heitikis in greenstone is ascribed to the custom of wearing an adze pendant on the breast. When this type of pendant was supplanted by the symbolical figure of Tiki, intrinsic and sacred values were combined in the one ornament.
Among the amulets worn as pendants is a headless human form, and one in the shape of a leg.

The hei-matau is a hook (which may have the head of a man, bird, fish or seal) worn as a fishing charm; it was trailed in the water as the Tohunga (priest) recited the karakia, or appeal for suceess. 
The peka-peka (the name of the bat) is a sinuous elongate ornament, with a bird or human head earved at each end. It resembles the marakihau, in the form of a fish with a human head. The two latter are North Island types and there are many pendants displaying features from both of them. Another series is regarded as representing conventionalized fish, eels and lizards, the snake interpretation being discounted because of the absence of this reptile in New Zealand.

The koropepe is a coiled pendant. An important group of amulets represents birds, and is considered to be akin to the wearing of a live bird, or of its feathers, beak, skin or bones as an ornament.

Other pendants are shaped like fishhooks, harpoon-heads, or are simply straight or curved strips in which the beauty of the stone is paramount.

Polished lumps of greenstone, called whakakai, are also worn as ear-pendants.

The kakaporia is a ring attached to the leg of a tame parrot.

A unique pendant is the representation of a mako shark's tooth in pounamu.

Antiquity of Greenstone Working.

Students of Maori life have long debated the question of when a knowledge of greenstone was aequired. The idea that Ngahue took a block of pounamu back to Hawaiki with him, thus suggesting that it was known before the Maoris reached New Zealand and formed an inspiration for their migration, is now regarded as a legendary manifestation of the deep regard the Maoris possessed for greenstone. As a raw material it was so important in their culture that in Maori mythology its origin was pushed back to the reation period. The limited distribution of the stone also discounts this idea, and for this reason it is most improbable that the Rarotongans visited New Zealand to get it by canoe before the Maoris reached their present homeland.

Archaeological investigations by D. Teviotdale, Dr. R. Duff and others, have revealed that the early period of occupation of New Zealand was by a Polynesian people, called the Moa-hunters because the now extinct moa birds were an important part of their diet. The Moa-hunters oceupied the two islands from about 500 A.D. until the great canoe migration of 1350 A.D. when modern Maori eulture was introduced and sealed their doom. Although nephrite implements were used by the Moahunters, only two authenticated pieces of pounamu are known from their camp-sites. It is thus now established that they were only casual workers of the stone. Duff believes in the probability that the Arahura deposits were discovered prior to 1500 A.D., during the Waitaha period, and that the stone was then traded to the North Island. Further, that it was also traded to Southland to be made into adzes and minnow fish-hook shanks. In fact, he thinks, from a Moriori myth, that pounamu was discovered not later than the fourteenth century. It has thus been worked in New Zealand for about five centuries. The Ngati-mamu did not know of its source, nor did the Ngai-tahu until the mid-seventeenth century. The Otago district greenstones from Lake Wakatipu and other sites were exploited at a much later date. According to evidence from his archaeological investigations, Duff pointed out that when nephrite appeared commonly in South Island sites it was in North Island forms, including the mere, hei-tiki, hei-matau, ear-pendant, leg-rings, etc., in the Ngai-tahu camp-sites of the eighteenth and nineteenth centuries. During several centuries the North Island Maoris evolved many highly developed kinds of greenstone implements and ornaments, and the craft was taken by them to the South Island, chiefly by the Ngai-tahu, just after 1600 A.D. Greenstone was scarce in the South Island, apart from the West Coast, because the almost impassable Southern Alps prevented trade to the east. On the other hand, a well established trade existed to the North Island up the west coast, and Captain Cook saw one party bringing pounamu to Queen Charlotte Sound Maoris.

\section{Greenstone and the White Man.}

By the time the white man arrived in New Zealand the cult of greenstone was at its height among the Maoris. Its exchange value was high, and for it were received 
skin and feather eloaks, flax garments, food, obsidian, weapons and other articles. Steel axes, however, soon supplanted those of greenstone and the latter had gone out of use by 1840. Many of the pounamu adzes were carved into hei-tikis, so that large numbers of the latter are post-European in age. The white man first visited Westland in 1846 , but from 1865 onwards, when miners sluiced for gold in the Arahura and Taramakau rivers, pounamu became plentiful and picked pieces were sold in 1891 at one shilling per pound. Counterfeits then began to appear. Dr. H. D. Skinner stated that thousands of penci! and eigar shaped pendants, often made of heautiful stone, were sold to the Maoris during this period, and were re-sold to tourists and collectors. By this time also, he said, the Maoris' belief in the magical value of their amulets had been undermined to a very great extent. Meres, heitikis, and other carved pendants were produced as the white lapidaries became skilful in working greenstone, and many of these specimens, after being handled by the Maoris for one or two generations, became such perfect replicas that they could not be distinguished from the genuine pieces. Counterfeit hei-tikis and meres made of bone were also sold in large numbers.

There was, according to T. Conly, a boom in this trade between 1900 and 1902, and again during World War II for the American forces in New Zealand. Popular additions to the range of products were hearts, watch-chain links, brooch bars, crosses, tiger's claws, shark's teeth, scimitars, paper-knives, and various pendants, while the hei-tiki became a sharp-edged and hideous little demon. The white man did not favour the same coloured greenstones as the Maori, and with the former the kawakawa, inanga and tangiwai varieties were unpopular. There were several factories in Dumedin, the centre of the trade in New Zealand, but replicas were also made in Berlin and probably Birmingham. The modern meres may be distinguished in bearing three grooves on the butt and usually by an even eylindrical hole through the handle. New Zealand greenstone was exported to China. From England, a green malachite (called by the Maoris " the jade of England") was imported and worked up into specimens for sale.

The Australian Museum possesses a fairly representative collection of Maori greenstone objects, although it is limited in number. It was augmented considerably in 1951 when the late Sir William Dixson presented a collection which included seven meres, twenty adzes and chisels, forty-one hei-tikis, fifty-five ear-pendants, three pekapekas, five hei-mataus, two kakaporias or bird-leg rings, and several other pendants. Some ancient pieces are included in this collection but the majority probably originated since the 1860 's. Notable examples in our collection are illustrated.

(The map in the first instalment of this article (page 180) was compiled by Dr. H. D. Skinner and published in Transactions of the Royel Society of Xew Zealand, 1935.) 


\section{A Man and a Museum-Sir Hans Sloane, Bart.}

\section{By JOYCE ALLAN.}

$\mathrm{L}$ IKE many visitors to England in the wonderful Coronation Year of 1953, I retraced my steps time and time again to favourite scenery, and to galleries and museums with their wealth of historical association, their libraries or their art and seience treasures. Exhibitions were everywhere. In the daily papers on one occasion alone, in London. I counted no less than thirty-six major exhibitions set down for that particular day. Was it any wonder that a daily visit to one or two at least of these became a "must" for many visitors to that great city! Small galleries and odd little museums in tuckedaway streets and corners vied with the big galleries and museums - the Tate Gallery, the Royal Academy, the National Art Gallerv, the Victoria and Albert Museum, the Science Museum, and the most famous musenm in the world. the British Musenm -in their efforts to display their finest and their most interesting objects in honour of their new Queen.

The British Museum with its magnificent collections, and its wonderful classical building, would naturally have been my main attraction, as it is to so many visitors. It was, in 1953 , apart from its special display for the Coronation, also celebrating its bicentenary, so the dual purpose served not only to give a face-lift to its buildings but to produce an even more interesting exhibition of books, manuseripts, art treasures and natural history objects. The British Museum is situated at Bloomsbury, London, but with its rapidly increasing collections it long ago outgrew its size, and the natural history portion of it was removed to a very fine building of its own at South Kensington, now distinguished as the British Museum of Natural History, South Kensington (distinct from the Science Museum, that is near by). In a conspicuous place in the entrance hall of this Natural History Museum, just where I could see it as I passed through the hall almost daily en route to the Shell Department, was a very interesting little exhibition concerning Sir Hans Sloane, Bart. (1660-1753). It was, actually, an exhibition within an exhibition, since this was part of the British Museum's Bicentenary Celebration.

Repetition of a personal name, especially when applied to locations, generally arouses curiosity as to its origin. There must be many Londoners themselves, apart from visitors in the vicinity, who, passing by Sloane Station, Sloane Square, Sloane Street, Sloane IIouse, for instance, have wondered who and what was Sloane. At

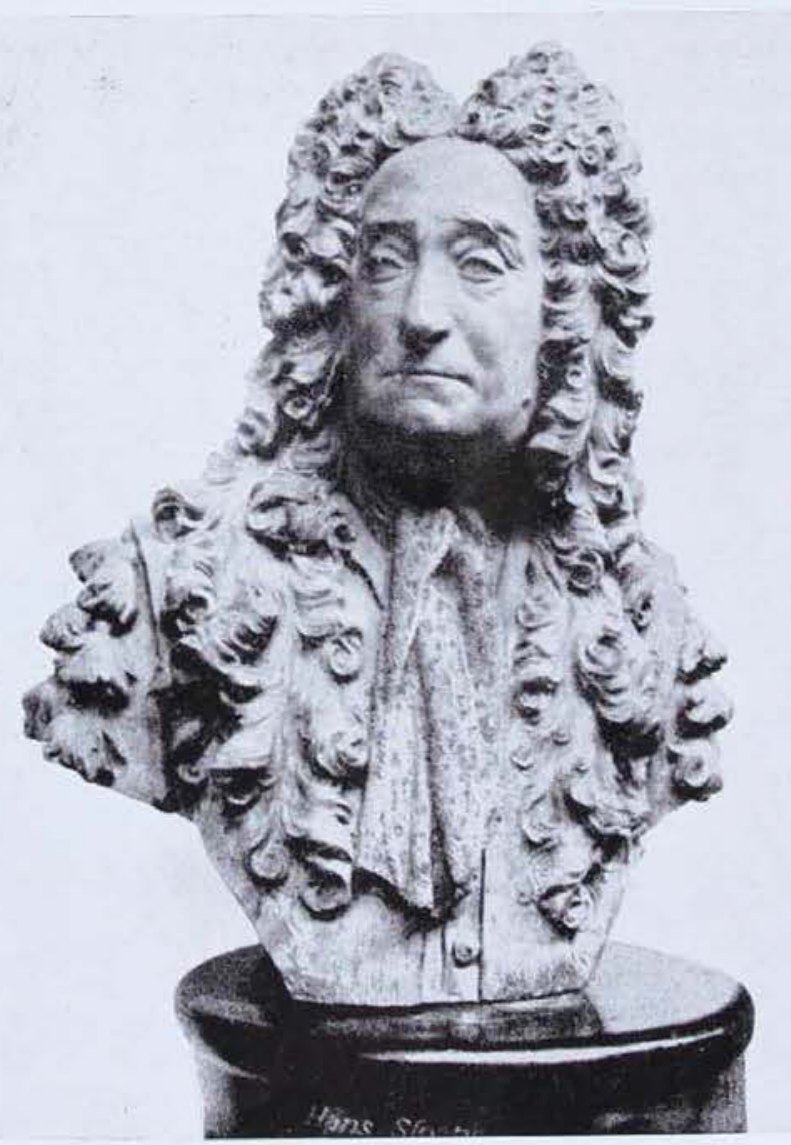

Bust of Sir Hans Sloane by John Michael Rysbrack, in the British Museum.

From: Sir Hans sloane of the British Museum, by de Beer. 
the exhibition mentioned, in an attractive series of cases, by a compact exhibit of specimens, illustrations and explanatory labels, the visitor is told precisely what is the link-up between a man named sloane and the British Museum of Natural History, and of course, the British Museum in toto. In a nutshell, visitors are told that the huge collections of natural history objects - shells, fishes, insects, minerals, fossils, and plants, as well as many curiositiesamassed by Sir Hans Sloane during a long and busy life as an influential physician, for his own and his friends' pleasure, formed at his death the basis of the present British Museum of Natural History.

Born in 1660 of Scottish parents who settled in Kellyleagh, County Down, Hans Sloane studied medicine in London and later on the Continent, taking his Degree of Physic at the University of Orange. He then returned to London where he set up practice in 1684, and was successful from the start, although accounts say he was never a robust man. It was most fortumate for him, and for the scientific world in general, that an early appointment as Physician to the Duke of Albemarle enabled him to accompany the Duke to Jamaica, where he went as Governor, as it gave Sloane the opportunity to make observations and notes on the natural history, both of the plant and animal life. of that region. As a result, a debt of gratitude is now owed to him for the two important works he compiled, namely, the Catalogue of Jamaican Plants, 1696, and the Natural History of Jamaica, a huge volume which appeared in two parts in 1707 and 1725 .

Hans sloane married the widow of a Jamaican sugar planter in 1695. He must have led a tremendously busy and interesting life. He held the posts of First Physician to Queen Anne and later to George I, who ereated him a Baron in 1776; Physician General to the Army ; President of the Royal College of Surgeons; Secretary (and later President) of the Royal Society, a position he held for thirteen years; and yet, apparently, he was able to spend a greater part of his life gathering round him his natural history collections, which he carefully catalogued and set up in museum-like fashion and which became an endless source of joy and entertainment to himself and his many distinguished friends.

The huge collections were transferred to his new home, The Manor. Chelsea, when he retired from his medical practice at the age of 83 , and there the collections, which
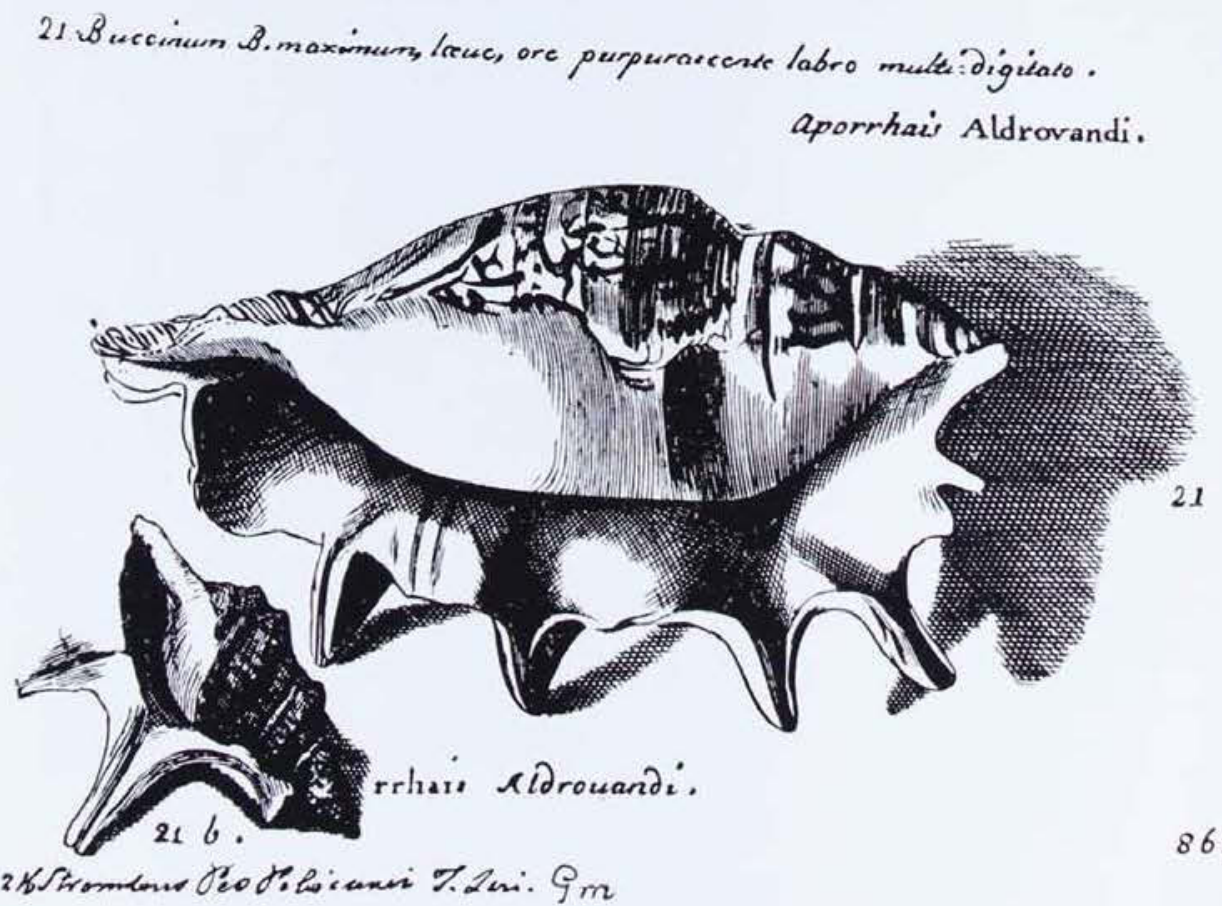

Reproduction of an engraving of two shells, executed by Susanna and Anna Lister which appeared in Historia Conchyliorum, Liber IV, 1688, by Martini Lister. It shows the high standard of accuracy reached by these two early natural history artists. The shells can be easily recognised as an immature specimen of the tropical seas spider shell. Lambis lambis (21), and the odd shaped pelican foot of the Atlantic-Mediterranean regions, Aporrhais pes. pelicani (21b). Many old engravings were made from shells in Hans Sloane' collection. 
had been added to greatly by many contemporaries in the meantime, were kept up-to-date. At his death, these, apart from a library of some 50,000 books, were said to number in the proximity of 100,000 specimens. Specimens which at that time were either extremely rare or quite unknown previously, were brought back by friends from such places as the East Indies, Magellan, Japan, and from most parts of the then known world. This very enthusiastic seventeenth century naturalist also added to his collections by purchasing other collections that became available, such as that of his friend and contemporary, James Petiver (1658-1718), whose album of insects gives a good insight into the mode of mounting such specimens at that time.

Sir Hans Sloane died after a very full life at the age of 93 , and his tomb is in Chelsea old Church; an interesting hour or so can be spent wandering round the region of this charming suburb with which he was for so long associated and which still bears his mark in many ways. After his death, by an Act of Parliament, the collections were purchased, with some others, and this marked the inception of the British Museum, first opened in Montague House in 1759, and later in the beautiful building at Bloomsbury which had been completed in 1845. Even that eventually proved inadequate for growing collections, and so the natural history collections were removed from it to the large, imposing Natural History Museum, in Cromwell Road, South Kensington, which had been built on a site purchased in 1863, and opened to the public in 1884 . This building suffered damage during the last war from a H.E. bomb in the adjacent road; glass splinters from shattered windows are still firmly embedded in some of the cabinet doors in the shell department. As a result, however, a lovely gallery section has been rebuilt to house a British birds exhibit.

The life of a museum is maintained by additions of new material over the years, whether through purchase, donation, or staff field work. Early collections are often transferred, for various reasons, from one room to another, from one case to another, incorporated with other material and so on. This is mostly due to lack of spacea museum's great bugbear-or acquisition of specimens in better condition. Many of the earlier collections, like that of sloane and later large British ones, vere used as the basis for fine publications that exist in world museums and libraries to-day, and which scientists still must refer to in the course of their work. Such men as Lamarck, Grey, Cuvier, Leach and dozens of others used material from private collections to illustrate their monumental treatises. It is fascinating to come across the actual specimens in museums, that have been figured in works published some two hundred years ago. Sometimes the specimens are not easy to locate; much sorting and studying and reference to literature and to faded original labels written in a spidery hand, have to be carried out before one can be certain that the one or ones in question are those applicable to the case. In most cases, the work of early illustrators was so good, and so true to type in its delineation, that relationship between an illustration and description in a scientific work, aceomplished as much as some hundreds of years back, and the actual specimen upon which these were based, can be assumed with little difficulty.

The shells in the Sir Hans Sloane collection show this remarkably well. He had more than five thousand at his death. His name is familiar to museum eonchologists in Australia, as in many parts of the world, through its occurrence in centuries-old volumes, actual specimens from his collection being known by illustrations only, many of which appeared in Martin Lister's Historia Conchyliorum, or the History of Shells, engraved in copper by the author's two daughters, and show the high standard of perfection reached by seventeenth century artists. It has been a revelation to me, through the courtesy of Dr. W. J. Rees and Mr. G. Wilkins, to see the actual specimens in the British Museum of Natural History, in most cases with the original catalogue number in faint ink, and to compare them with their illustrations in a 


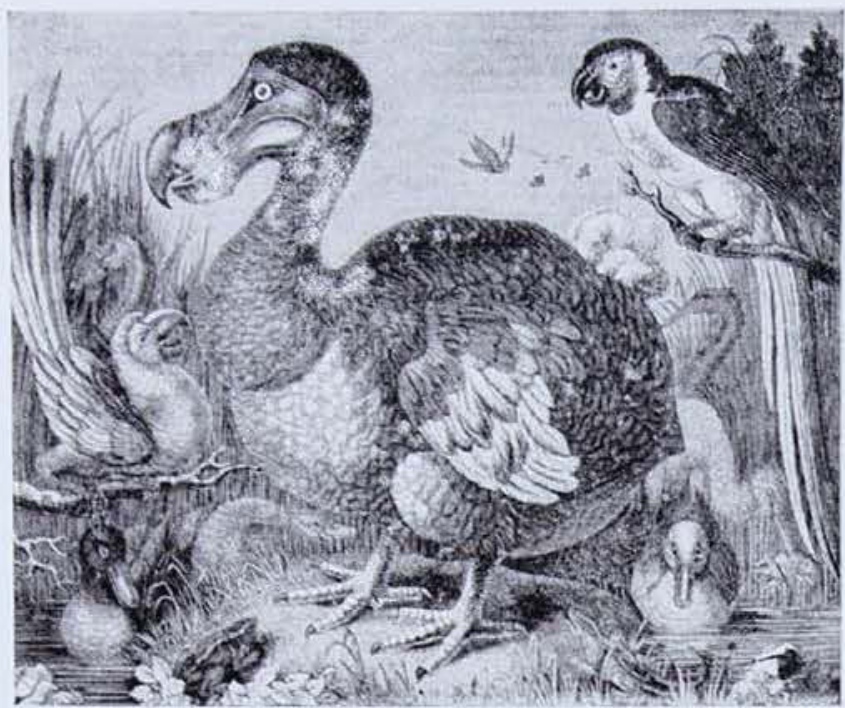

The celebrated picture of the extinct Dodo, painted in Holland from a living bird brought there from St. Maurice's Island. The painting came into the possession of Sir Hans Sloane and after his death passed to the British Museum. It is now displayed in the entrance hall of the British Museum of Natural History, South Kensington.

natural history book. One excellent example I recollect is a Chinese freshwater mussel with its artificially produced culture pearls attached (many centuries ago the Chinese were adepts at pearl culture) and its faithful reproduction in an early and valuable volume. But there are many others of similar interest, and knowing this, the reader may understand how the famous John Evelyn felt when he wrote in his Diary, 16th April, 1691-

"I went to see Dr. Sloane's euriosities, being a universal collection of the natural productions of Jamaica, consisting of plants, fruits, coral, minerals, stones, earth, shells, animals, and insects, collected with great judgement; several folios of dried plants, one which had about eighty several sorts of ferms, and another of grasses; the Jamaica pepper in branch, leaves, flower, fruit, ete. This collection, with his Journal and other Philosophical and natural discourses and observations, indeed very copious and extraordinary, sufficient to furnish a history of that island, to which I encouraged him".

And the reader mav wonder just what Sir Hans Sloane would now think, after two hundred years, if he were here to see how his collection, that he so proudly shared with all in his day, had helped to produce the monumental British Museum of to-day.

\section{"Face Lift" for Museum's Giant Sloth}

\section{By H. O. FLETCHER.}

$\mathrm{R}$ ECENTLY the plaster cast of a skeleton of the Giant Sloth, Megatherium, which has been exhibited in the skeleton gallery of the Australian Museum for the past eighty-three years, was completely renovated. The colour was changed from an uninspiring dull red to the more natural colour of bone. The change in colour made a great difference to the appearance of the exhibit and it has since created a great deal of interest among visitors.

During Pleistocene times these extraordinary giant sloths were monarchs of South America. Huge, cumbersome creatures, they attained a length of eighteen feet and possessed a strength far greater than in any other known mammal. This strength is exemplified in the skeleton, the bones of which are more massive than those of an elephant. The thigh-bone, in which the circumference is equal to that of the length, is three times the size of the similar bone in the elephant. The strength of the giant sloth is indicated not only in the size of the bones themselves, but in the large structures used for the attachment of powerful muscles and tendons.

The skeleton in the forepart of the body is slender in comparison with the enormous weight found in the hindquarters. The tail is massive and powerful; with it and its tremendous heels fixed firmly into the ground, like a tripod, the sloth was free to exert the full force of its muscular arms and claws. 
Knowledge of the giant sloth first came to light when its fossil remains were found buried in the alluvium of the Luxan River in Argentina. This was in 1789 and the Marquis of Loreto, then Viceroy of Buenos Aires, forwarded to Madrid the remains of what he stated was "a strange giant animal ". In 1795 a turther specimen was unearthed at Lima and, together with other fossil bones of the same type of creature from Paraguay, was sent to spain. The fossil bones from Paraguay were then in the possession of Father Fernando Scio.

An early writer on the giant sloth claimed that Spain was in possession of three imperfect skeletons, but later, in 1821 , it was reported that no trace of the fossil bones from Lima or those belonging to Father Fernando scio could be found. The knowledge of this strange extinct animal from South America was therefore at this time restricted to a single imperfect skeleton from the River Luxan.

After an exceptionally long period of drought in the Argentine the waters of the River Salado, one of the tributaries of the Rio Plata, and south of Buenos Aires, became lowered to such an extent that the bed of the river was exposed. In it was found embedded a great pelvis bone of a giant sloth and this important fossil was presented to Sir Woodbine Parish by Don Hilario Sosa, on whose property it was found.

Realizing the importance of further fossil remains of the sloth. Sir Woodbine Parish, then Britain's representative in Buenos Aires, initiated an exhaustive search for them in the bed and banks of the River Salado. The search was successful and two additional imperfect skeletons were collected and forwarded to the Royal College of Surgeons in London. This material formed the basis of a research paper on Megatherium by William Clift, F.R.S., which was published in Geological Transactions, Second Series, Volume iii, page 437.

At this stage, however, there were insufficient fossil remains to enable a thorough account of the complete skeleton to be published. It was not until the year 1837 that additional specimens were collected from near Luxan and offered to the Trustees of the British Museum. In 1845 the fossil material was forwarded to London and Professor Owen was then able to clear up several doubtful details, particularly in regard to the giant sloth's food.

The Trustees of the Australian Museum in 1871 were keen to secure a plaster cast of this unique animal and the Trustees of the British Musemm were approached regarding the possibility of securing one for exhibition in the gallery. A complete skeleton was built up from fossil remains in the British Museum and from the collection of the Royal College of Surgeons and a cast from it was sent to Sydney the same year. It created great interest and for the past eighty-three years visitors have rarely passed the exhibit without commenting on the massive strueture and strength revealed by the skeleton. (See frontispiece.)

Powerful claws are shown fitted to the strong toes and fingers and these it was originally thought were used to loosen the soil around the roots of trees so that they could be easily pushed over and the leaves made accessible for food. The teeth of the giant sloth prove conclusively that it was herbivorous and its diet was exclusively vegetable matter.

The small living sloth lives in the treetops and possibly because of this fact some scientists put forward the suggestion that the great cumbersome giant sloth also climbed trees in search of tresh leaves and small twigs. Obviously this idea is untenable, but it was not until Professor Owen brought forward his conclusions regarding its method of obtaining food that the earlier ideas were discounted.

Professor Owen considered that the giant sloth actually pulled the tree down by sheer strength or broke it off near the ground. His opinion was that every detail of the immense skeleton proved that the sloth sat up on its tail and haunches, as if on a tripod, while it grasped the tree in its powerful arms and literally uprooted it or snapped it off. 
The Rev. H. N. Hutchinson in his book Extinct Monsters, published in 1896, gave a very full account of the early history of the giant sloth. He describes very vividly in the following words a sloth in the act of securing food: "It is not difficult to form a mental picture of the great beast laying siege to a tree, and to conceive the massive frame of the Megatherium convulsed with the mighty wrestling, every vibrating fibre reacting upon its bony attachment with the force of a hundred giants".

The teeth of the giant sloth, as in the living sloths and their close relatives the armadillos, are interesting in that they are restricted to the back of the jaw and entirely absent in the front part. There are five molar teeth on each side of the upper jaw and four in the lower. They are in the form of hollow, prismatic cylinders, 7 to 9 inches long, straight, and set in deep sockets. The teeth do not wear away as sometimes found in other herbivorous animals and the one set lasts for the life of the sloth. Constant replacement is brought about by an upward growth and the surface always has a pair of transverse ridges, an ideal development well suited for the grinding of vegetation.

The extinct giant sloths lived during Pleistocene days in the southern part of the American continent. Associated with them were other just as strange animals, including the now extinct giant armadillos and the Great Ant-eater. They all belong to the Order Edentata, members of which, if not entirely toothless, are nearly so. These curious animals roamed over the South American countryside and it is obvious from the uselessness of their body structures that life must have been enjoyed in an environment admirably suited to them.

The reason for the extinction of the giant sloths, or any animal group, is always to some extent a matter of speculation. It is a recognized fact, however, that any tendency of a species in its evolution towards large size, or a bizarre development of structural features, is a sure sign that it is nearing extinction. Such a development brings with it the loss of active movement and an awkwardness which makes the

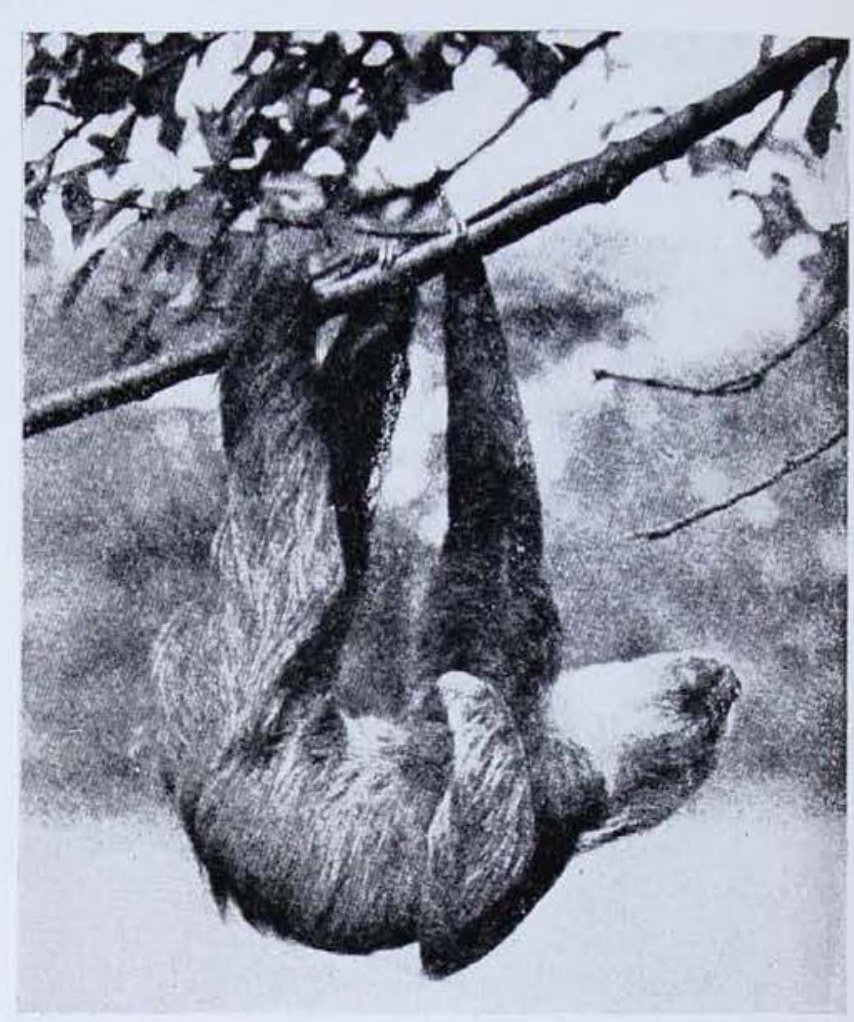

Two-toed Sloth.

Photo, Sanbora, in "The American Natural History".

animal unsuited to overcome changes in environment caused by prolonged droughts or change in climate.

The extinction of the giant sloths may possibly be explained in this way. Towards the close of the Pleistocene period there was a change from temperate conditions to semi-aridity and in some areas the country altered appreciably. Anchored to their immediate locality by their giant bodies and slow movement the giant sloths would be forced to face the hazards of rapidly drying watering places surrounded by mud and marsh. Once caught in the mud it would be an impossibility for such weighty animals to extricate themselves. It would be only a matter of time for them, with a limited distribution, to become extinct, whereas smaller and more active animals could move off in search of food and water.

Geologically speaking the extinction of the giant sloths and other giants of Pleistocene times took place only a short while ago, but in numbers of years could be from 100,000 to 300,000 years ago. This period of time is not long when it is considered that a longer period is usually required for the evolution of a new species. 
It is interesting to note that there are species of sloths in South America to-day, including the Three-toed and Two-toed Sloths. These are minute creatures when compared with the extinct form; the threetoed sloth is only 21 inches in length and has a span of 32 inches between its outstretched arms. Other species are slightly larger in size.

The habits of the living sloths are entirely different from the giant sloths of the Pleistocene period. They live almost entirely in the tree-tops where throughout their lives they hang upside down under the branches by means of the feet, which are simply four hooks. These sloths are a picture of helplessness when seen on the ground and their facial expression has been recorded as "one of complete and farreaching stupidity ". To escape its few enemies which can share the tree-tops the sloth lives far out on the ends of slender branches. It has developed protective coloration and camouflage to a great extent as the hair of a sloth is long, wavy and coarse, resembling grass rather than hair. In colour and general appearance the sloth an merge with its surroundings in a remarkable manner.

Strangely enough the living sloths. although utterly helpless on the ground, appear to he just as much at home in the water as they are in the tree-tops. One ohserver has recorded that it uses an overarm backstroke which could not be critirized in the Olympic Games. Under norma! conditions a sloth will not swim in this position. but, if placed in the water on its back will not bother to turn over but moves off at a rate as fast as, if not faster than, when swimming in the natural position.

The presence in South America of a number of species of living sloths, living an arboreal life, makes it almost certain that the giant sloth. Megatherium, was not ancestral to them. They must have been contemporaneous with the ground-living giant sloths and were themselves originally ground dwellers, but some of them, utilizing their strong and long claws, specialized in a life in the trees. They have survived, whereas those which remained on the ground attained great size but are now extinct.

\section{Fossil Remains from Wombeyan Caves}

In 1896 Dr. R. Broom described new species of marsupials from a bone breccia deposit near the Wombeyan Caves, New South Wales. He considered the deposit to be of considerable age and suggested that the fossil remains indicated a fauna living in late Tertiary times. In a paper published in the Proceedings of the Linnean Society of New South Hales (Vol. xxi, Pt. 1, 1896). Dr. Broom described a number of new species, including jaw fragments, which he described as $B u r$ ramys parvus and Palaeopetaurus elegans. Unfortunately the fossil material showed very few structures which indicated the affinities of these two genera and they have been a puzzle to workers in vertebrate palaeontology ever since.

Recently, Professor R. A. Stirton (Chairman of the Department of Palaeontology, University of California), and Mr. Jim Connell (photographer, of Hollywood, U.S.A.), in association with Dr. F. W. Booker and Mr. H. O. Fleteher, visited the Wombeyan Caves and re-located the cave breccia from which Broom's material had been collected. Additional fossil bones were collected and it is hoped that when they are examined further light will be thrown on the genera described by Dr. Broom.

The deposit is situated in a small depression on the hillside just above the opening of a cave, which, although explored, is not open to the public. The matrix is hard and contains innumerable small bomes very closely packed together. This feature is so characteristic of the deposit that Professor Stirton is of the opinion that the small bones were originally derived from an aceumulation of owl pellets. There is little doubt that the bone deposit at one time represented the floor of a cave, the walls and roof of which have weathered away.

Last year Professor Stirton spent a consider able amount of time in Australia, devoted to recearch on the late Tertiary and Pleistocene marsupial faunas. He is continuing this work during his present visit and will be carrying out extensive collecting at Lake Palankarinna, east of Lake Eyre, and in the Darling Downs of Queensland. Mr. Connell, who is accompanying him, is preparing a film on Professor Stirton's activities in the field. 


\section{Photography in the Field: Hints on Equipment for the Naturalist}

By HOWARD HUGHES.

W ITH the coming of spring and the increased activity of our native animals, the naturalist will be in the field at every opportunity, loaded down with collecting gear, sketch book and camera. Also at this time of the vear inquiries will reach the Museum on how best to photograph the many interesting subjects encountered on a collecting trip. Many of these queries would be unnecessary if the inquirer had devoted a little more time to the study of photography in general, and had become thoroughly conrersant with his own particular equipment. The naturalist knows how and where to find his specimens, so in this short article I will confine myself to elaborating a few points which may assist him in his photography.

Firstly, the beginner should not be tempted to purchase expensive equipment until his experience and needs demand it.
An expensive camera does not make a good photographer. Basic requirements are a camera with a lens capable of focussing on an object two feet from the camera, a long eable release, and a good solid tripod. A long focal length lens, extension tubes and flashlights can come later; each piece of equipment. however, should be the best you ean afford: often cheap equipment is low priced because of the omission of some valu. able asset.

Today there are many types and makes of camera on the market, each good in its own class: therefore the choice of equipment resolves itself into one of personal preference. For my own work I use a single lens reflex camera and a triple extension bellow type) plate or eut film camera. With the single lens reflex it is possible to watch a small animal right up to the instant of exposure, checking the focus continuously. and not worrying about parallas eaused

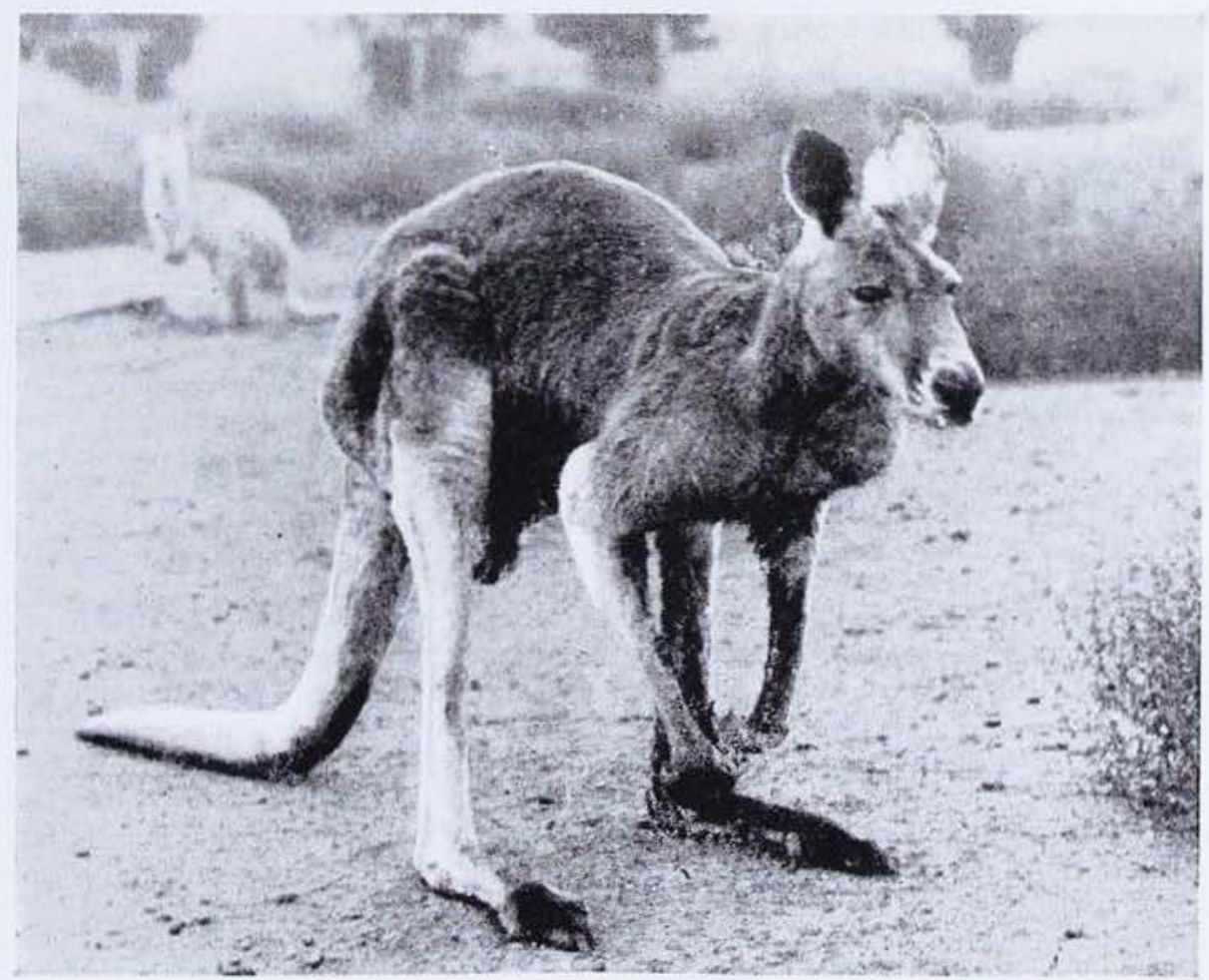

Red Kangaroo (Megaleia rufa) taken on a $6 \frac{1}{2} \times$ $4 \frac{3}{4}$-in. glass plate negative. The main subject is in sharper focus than its surroundings and is thereby separated from them.

Photo.-H. Burrell 


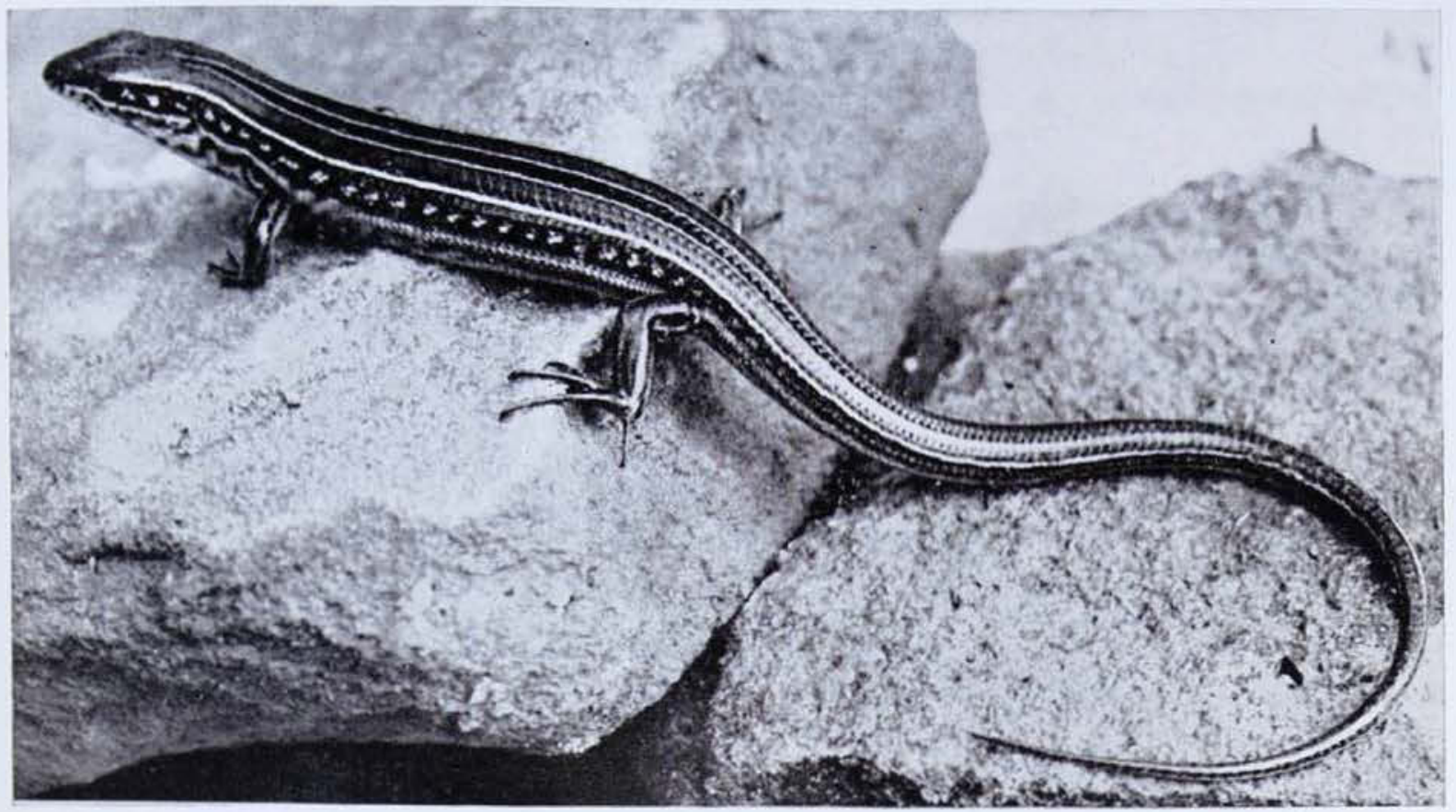

Striped Skink (Sphenomorphus australis). For this photo a glass negative was used, $2 \frac{1}{2} \times 3 \frac{1}{2}$ in. The skink was placed in position after focussing on a similarly shaped object.

Photo.-H. Cogger.

by an uncorrected viewfinder. The obvious disadvantage of the plate camera is that the subject may move out of range whilst the plates are being inserted in the eamera. The perfect camera for every worker has not yet been produced and in any case what is a major disadvantage to one person may be of little concern to another.

For those who prefer $35 \mathrm{~mm}$. there is a wide range of eameras available. One firm is planning to market a kit of frames, supplementary lenses, microscope attachment and flashlight unit for its own $35 \mathrm{~mm}$. product. The set of three metal frames slips on to the camera body, numbered to coincide with supplementary lenses which slip on to the taking lens. When an object is situated within the limits of the frame it is automatically in focus and centred in the negative image.

Grey Fantail (Rhipidura flabellifera) taken with a single lens reflex $35 \mathrm{~mm}$. camera. Good feather detail is necessary in bird photographs.

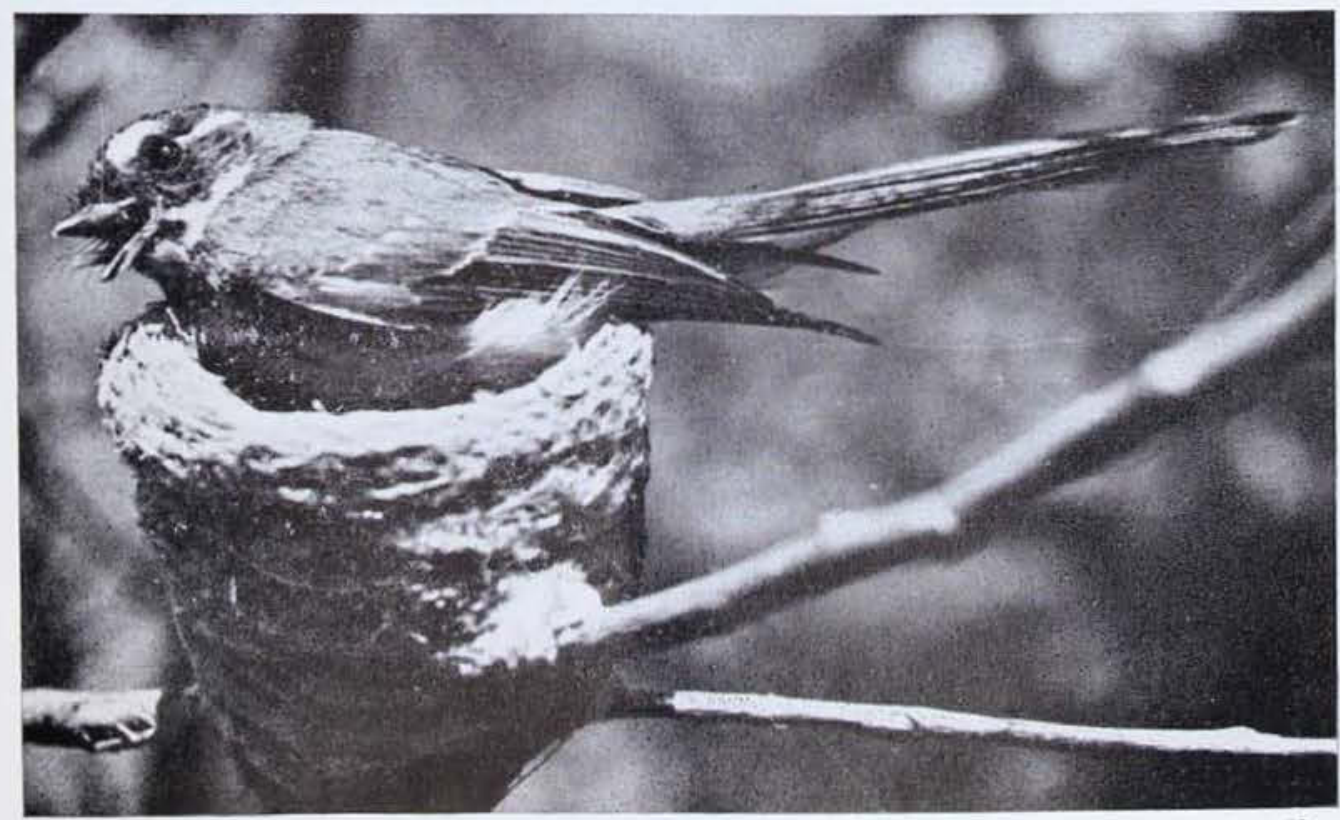


Whatever your choice, equipment should be simple and efficient. You should be so familiar with it that you can operate it by feel alone, even loading and unloading in the dark. Your whole attention should be on the moving subject, not diverted by the manipulation of the eamera and its accessories.

Before venturing into the field good experience and training may be obtained by photographing domestic pets. This piece of advice has often been received with a trace of disbelieving humour, particularly by owners of gleaming paraphernalia. Nevertheless if a photographer camnot produce a satisfactory print of the family eat or canary, showing good fur or feather detail, his time in the bush will be wasted. Incidentally, many insects and birds can be easily found and photographed in the average suburban backyard.

Many makes of film are on the market; for field work panchromatic type is the most commonly used because of its colour sensitivity and speed. In the field, plates or cut film can be reloaded safely at night without a dark room, but eare should be taken to move away from the camp-fire and other lights.

Frequently complaint is made that "the pictures I took would have been good only so-and-so ruined the film ". With home processing it is possible to detect a fault immediately and to apply the means for remedying it. Best results are obtained by processing your own film in the solutions recommended by the manufacturer. Leading manufacturers are always willing to assist with pamphlets and booklets on all stages of negative and printing procedures.

For a number of reasons many photographs shown me are not sharp and clear. The main reason for this indistinctness, apart from a lens of poor definition and quality, is camera movement caused by an unsteady grip on the camera, or incorrect focus. The first error is easily eliminated by the use of a tripod which, for convenience, should have a "pan tilt head" and be of solid construction. A loose-legged or wobbly tripod is useless. Because many subjects will be fairly stationary, or at least in an anticipated position, it is possible to focus directly on the subject through the viewfinder, or by measuring with a tape. When a subject is to move into an anticipated position an object roughly the same size as the intended subject can be placed in that position and the eamera focussed accordingly. Focus, or more correctly "depth of field" (the distance between the appreciably sharp points farthest from and nearest to the (amera), is governed by the focal length and aperture of the lens. A lens of short focal length usually has greater depth of field than one of longer focal length. This means that a lens set at three feet could have objects two feet and five feet in satisfactory focus at the same time. By closing the aperture to, say, F22, a wide margin is allowed for animal movement to and from the camera, while opening the lens aperture to, say, F4.5 decreases the depth of field and the subject can be in sharp focus against a softly focussed background.

The naturalist planning to make a photographic record of his work should visit the technical department of his bookseller where many books are available on every aspect of photography. A subscription to a good photographic magazine is an advantage as most of them devote a seation to nature photography from time to time and include examples of good animal photographs.

Under rigidly controlled conditions photography is easily mechanised for repetition work, but for the nature photographer conditions are never constant, each subject-bird, mammal or insect-requires a different technique and infinite patience. These techniques can be developed only by photographic experience and an. understanding of the habits of the subjects. Overseas nature photography is of high quality and much remains to be done by Australians to record their unique fauna in the manner it deserves. 


\section{An Elusive Jellyfish from Fresh Water}

\section{By FRANK McNEILL.}

$\mathrm{D}$ ESPITE the vast accumulation of our present day knowledge of natural history, there is always the chance thrill of some new discovery. Such things provide the stimulus and sustain the interest for a museum seientist in his work. Quite recently the advent of the unexpected took the form of a small humble jellyfish - a unique living example from fresh water. The find was of especial importance and added another unit to the great assemblage of animals now recorded from Australia.

To a zoologist the general run of jellyfish are rather commonplace. There are, of course, those special types with deadly stings, from tropical parts, and the giant ocean goer that has recently caused so much discomfort to local surf bathers. Each has received detailed attention in earlier issues of this magazine ${ }^{1}$ ). They all belong to the large and conspicuous group with the impressive name of scyphomeduace and are dwellers of the sea. The lesser known jellyfish are in a separate group termed Leptomedusae. While thes last are mainly marine, there are two unusual small kinds which live in fresh water. They have been found and described in other parts of the world, and have not up to the present time been recognized from Australia..

The two jellyfish groups differ vastly in their normal mode of propagation. Scyphomedusae always breed by producing young like in character to the parent. On the other hand, the Leptomedusae provide us with perhaps the most classical example of natural history phenomena, called "alternation of generations".

(1) MeNeill. F. \& Pore, Elizalonth-A neadl-, Poisonous Jellyfish, Aust. Mus. MAg., vol. viii, No. 4.

Pope, Elizabeth-Sea Lice or Jellyfish? Aust. Mus. Mag., vol. xi, No. 1.
This means that the progeny, bred in a normal (sexual) way from parent jellyfish, develop into a form of life totally unlike these parents. In other words, they revert to their primary state which is a colonial form of animal growth, delicate in character and comparatively small in bulk. This is a hydroid zoophyte which, in the marine field, is commonly attached by a stalk and is often shaped somewhat like a ferny plant. It is actually a colonv of tiny animal units, and when magnified is seen typically to be made up mainly of a great number of inter-connected cup-like structures. Each of these is the receptacle for a flowerlike body called a polyp which commonly carries a crown of tentacles. Some hydroid zoophytes are very plumose and comparatively large, while others are very simple and quite minute. Those found in fresh water, and popularly called Hydras, may lack tentacles, and may have only two or three polyps often only one. Another of

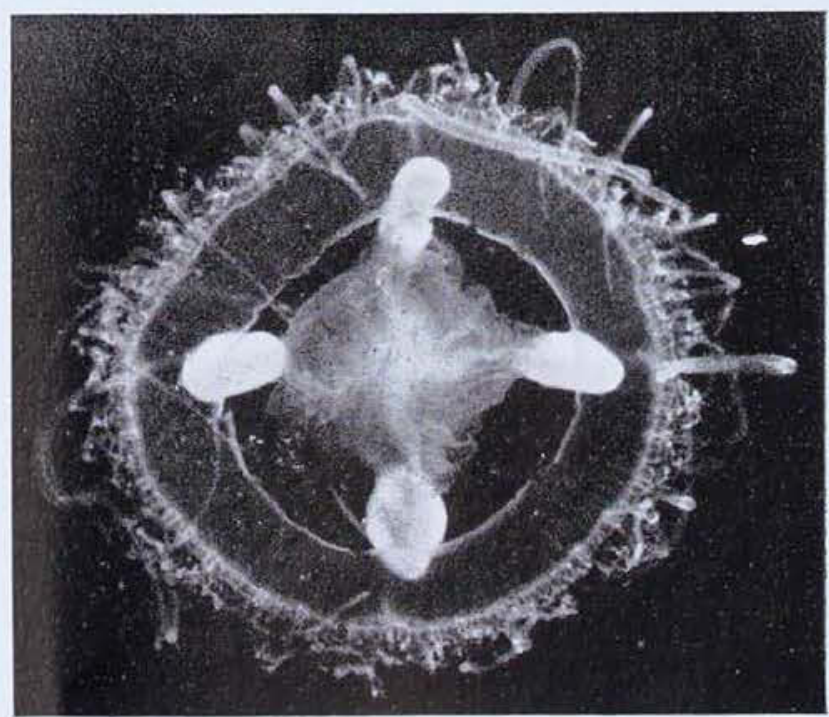

Ventral view of Craspedacusta sowerbyi, the jellyfish (medusa) taken from Sydney's water supply. The specimen was $9 \mathrm{~mm}$. in diameter, or almost three-eighths of an inch. 
their unusual characteristies is an ability to move about on their stalk-like bases. Unlike their great number of marine relatives, they are not sedentary or permanently attached.

Every keen aquarist knows a Hydra when he sees one on the water weeds in his fish tanks. In size it is macroseopic-just large enough to be seen with the unaided eye. The story of the recent discovery at the Australian Museum hinges on a species of Hydra which, when first found and described overseas, was given the technical name of Microhydra ryderi. At that time the relationship between this particular species of Hydra and an earlier discovered and described freshwater jellyfish, was not known. It will be shown later how the two are linked with our story.

Now the Hydras, like other hydroid zoophytes may, by a sexual process, produce progeny by direct development; i.e., in the form and character of the parent. The process earlier referred to as "alternation of generations", however, is one accomplished entirely without sex (asexual). Within certain structures of the hydroid, microscopic buds are developed and later freed into the water as actively swimming jellyfish, pulsating their umbrella-like bodies in the graceful manner of their kind. Jellyfish progeny of marine hydroids may be 3 to 4 inches across but those of the Hydras would grow to barely an inch in diameter. Upon mating, the jellyfish offspring revert back to the primary or hydroid zoophyte phase.

It was the rhythmic movements of the semi-opaque little jellyfish bodies which recently attracted attention in a bottled sample of water taken from a reservoir in the Sydney suburb of Balmain. The laboratory chemists of the Metropolitan Water. Sewerage and Drainage Board were viewing something they had never seen before in the local water supply. A specimen was sent without delay to the nearby Australian Museum for critical examination. Here the interest in the find was more profound still, and started the chain of events which have culminated in the writing of the present account.
To the Museum zoologists the jellyfish was equally new but was recognized as the product of a Hydra, exact species uncertain. Then, as will often happen with unique things of this kind, the unusual occurrence attracted the attention of the Sydney press. Publication of the facts quickly brought further scientific reaction. They were spied in Canberra, A.C.T., by a Museum staff colleague in the Australian Commonwealth Service. This Mr. E. F. Riek has a very specialized knowledge of the loeal freshwater fauna and pleaded by long distance phone for some of the live jellyfish specimens to study. It transpired that he had been searching and inquiring for such examples futilely over many years. Arrangements made with the Water Board officials enabled a special visit to be made to the dark and gloomy interior of the Balmain reservoir, where a few more jellyfish were sought and collected. Specimens were dispatched alive in a screw-top jar by plane, in the special care of an air hostess; Mr. Riek took personal delivery of them at Canberra Airport. He installed them in a special aquarium and had hopes that they might be able to mate and breed back to the Hydra phase. The experiment proved disappointing but the jellyfish remained alive long enough for Mr. Riek to study

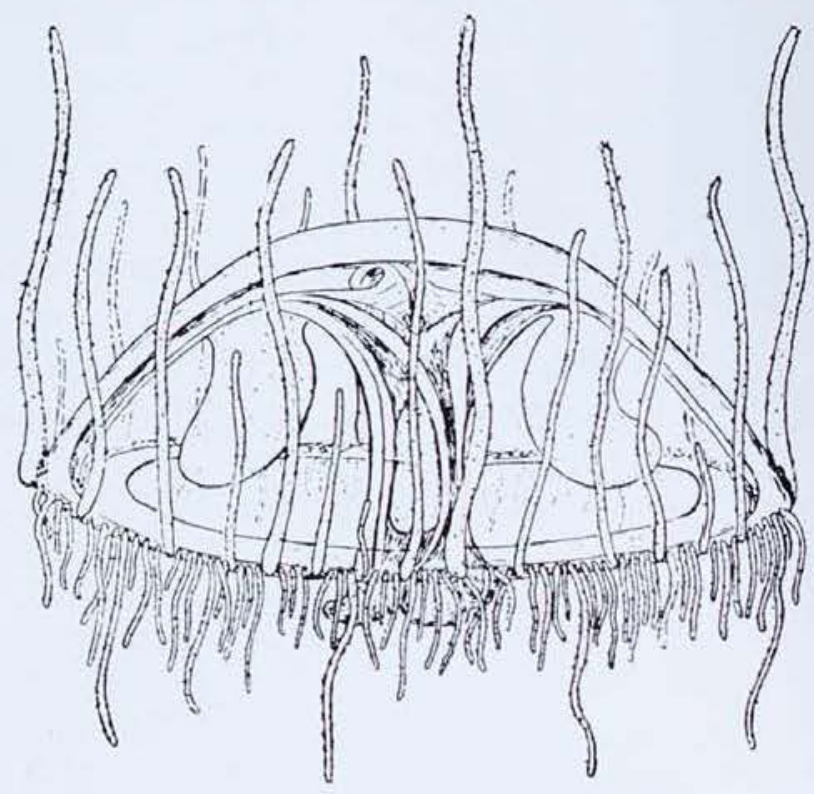

Diagram of a mature specimen of the jellyfish Craspedacusta sowerbyi. 
them critically and arrive at the conclusion that they were referable to a species technically named Craspedacusta sowerbyi. It was disclosed that this was discovered in 1880, in London, in a botanical pond planted with an Amazonian water lily, and is known to oceur in many lakes, ponds and streams of the United States and Europe. There is a supposition that the jellyfish was introduced from Brazil with the plant. As we now know, it was the Hydra species, Microhydra ryderi, which must have been responsible for the introduction. The jellyfish phase was its product, and Mr. Riek considers the Sydney, Australia, examples of great rarity. He stated that the micro-Hydras' production of jellyfish is unpredictable; in some cases as many as forty years have elapsed between reported appearances.

An interesting outcome of the established relationship between the Hydra and the jellyfish phase in question is that, in scientific nomenclature, the technical name of the jellyfish must stand for the two unlike animals; Craspedacusta sowerbyi was first discovered and described in print and thus has priority. How it came to be introduced at long last into an Australian water supply must remain a mystery. Suffice to say that the aims and interests of science have been served and the Water Board's latest intruder has been proved to be only a harmless trespasser.

\section{Tasmania's West Coast Mineral Localities}

\section{Mount Lyell}

\section{By R. O. CHALMERS.}

$\mathrm{T}$ ASMANIA'S wild west has a curious fascination for all who read about it or have visited it. It brings to mind Tasman's voyage of 1642 , when he first hove to off the rugged, inhospitable territory he named Van Diemen's Land. He did not land but noted two prominent mountains which, in 1798 , were named by Flinders after Tasman's two storm-tossed little vessels-the 200-ton Hecmskirk and the even smaller Zeehaen-when he and Bass first circumnavigated Tasmania. It is not generally recognized that Phillip and the First Fleet passed round this way because the existence of Bass Strait was at that time unknown. One recalls also the circumnavigation of Tasmania in 1815 by James Kelly in an open whaleboat. Kelly, a native of Parramatta, was harbour-master at Hobart Town. He discovered and named Macquarie Harbour, the Gordon River and Port Davey on the West Coast. In 1821 Governor Sorell established the first settlement at Macquarie Harbour as a place of punishment for the most recalcitrant convicts. As described in For the Term of his Natural Life, the first people to penetrate inland in this wild region were unknown convicts who, rather than endure the hell of Macquarie Harbour, preferred to risk the perils of unknown and forbidding territory. All probably perished miserably of cold and hunger.

The northern half of the West Coast is a prolific producer of minerals. In this region are situated the four major fields of Mount Lyell, Zeehan, Rosebery and Mount Bischoff, and so many other smaller fields and individual localities that there seems to be some truth in the often heard facetious remark that the whole of the West 


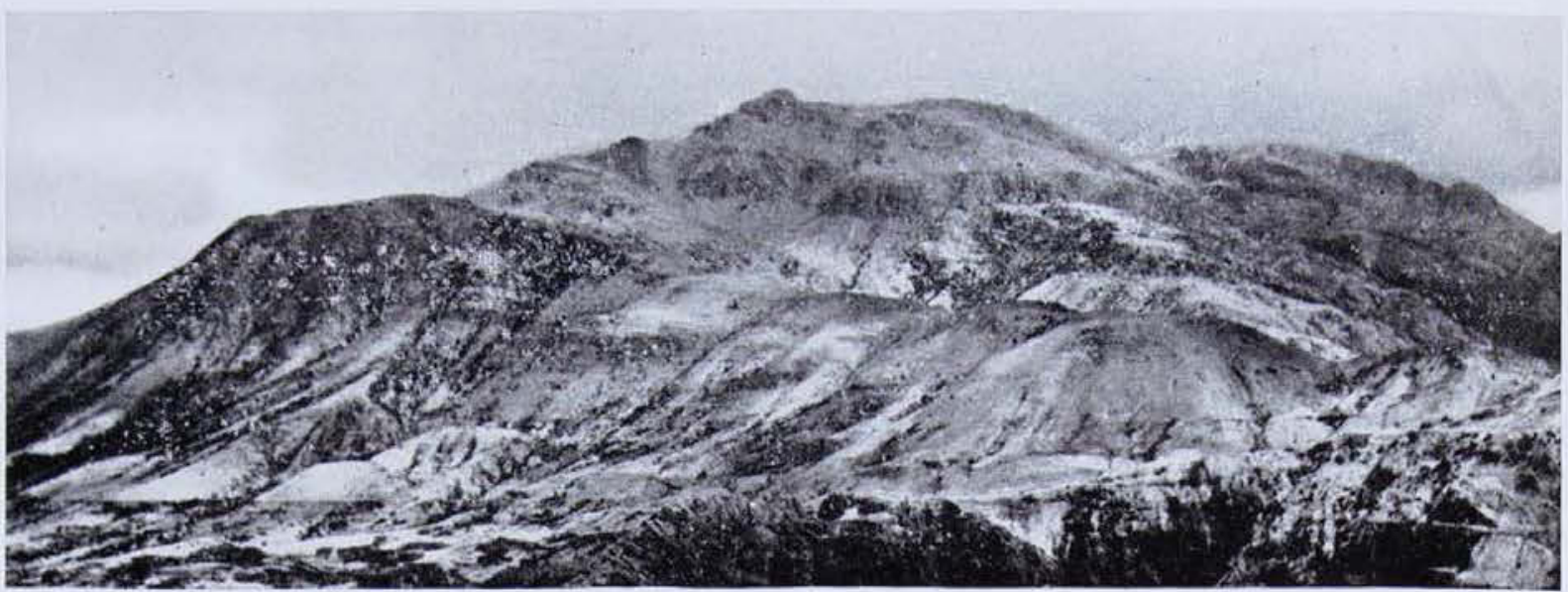

Treeless slopes of Mount Owen (above). The top of the "Iron Blow" open cut is seen in the foreground. Below: The U-shaped glaciated Linda Valley pictured looking east from the slopes of Mount Lyell. The Lyell Highway shows up in the centre of the scene.

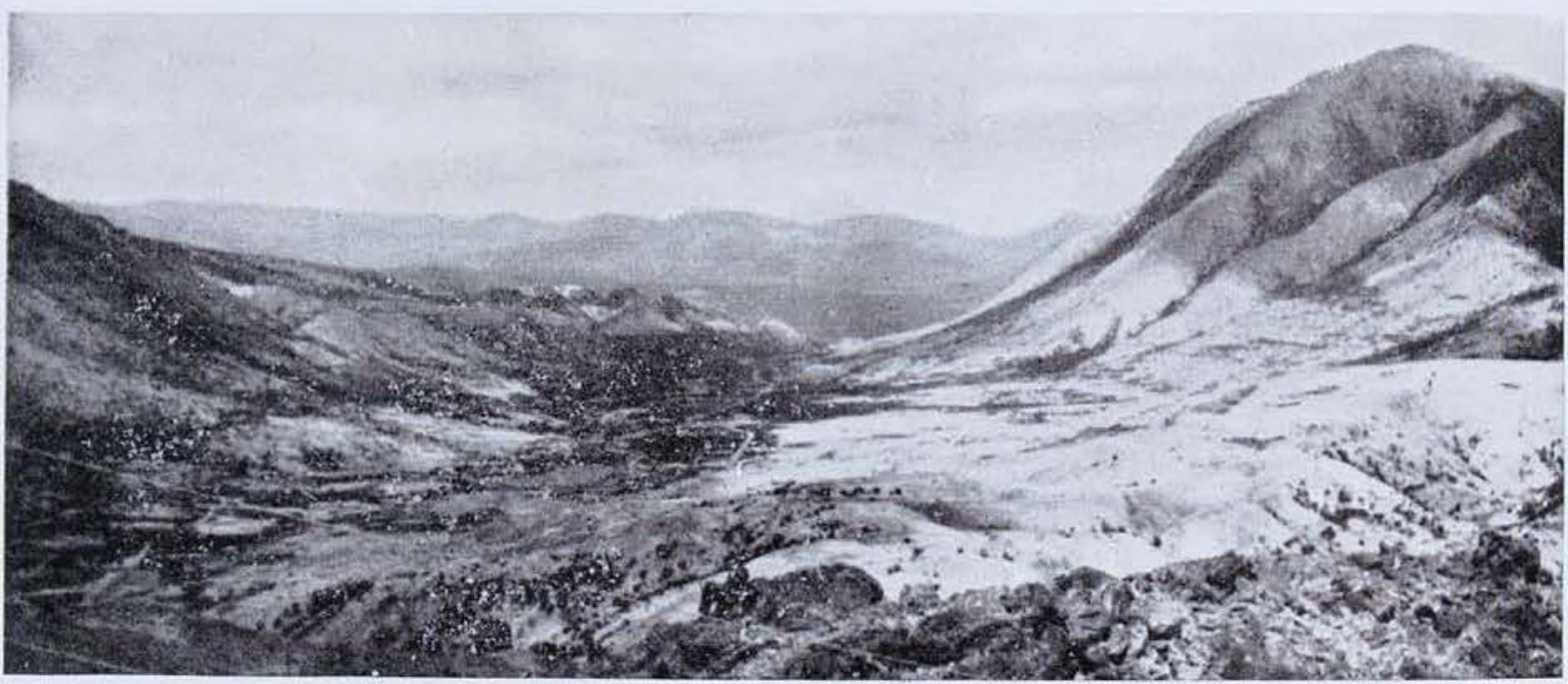

Coast could be worked profitably as one continuous open cut. In this and subsequent articles it is proposed to describe some of these localities, which the author visited in 1949.

\section{Mount Lyel.}

Mount Lyell is Australia's most famous and largest copper producer. The actual mountain is a member of the rugged West Coast Range which runs meridionally for a distance of some forty miles to the north of where the Gordon River enters Macquarie Harbour. The mountains of the range are isolated blocks of a very characteristic rock known as the West Coast Range Conglomerate. This most spectacular rock contains boulders many of which are a foot or more in diameter.
The principal mountains of the range, running from south to north, are Mounts Darwin, Jukes, Huxley, Owen, Lyell, Sedg. wick, Tyndall and Murchison. The latter' five were named after famous geologists of the day by Charles Gould, son of John Gould the famous ornithologist, and an early Government Geologist of Tasmania. Gould, in the period 1860-3, was the first to explore the Mount Lyell district and investigate its geology. He was one of the early few to approach from the east. He travelled up the Linda Valley, which he named Val de Chamounix, after the Swiss locality, on account of its glaciated appearance. He correctly attributed the general physiography of the West Coast Range to glacial action. It is now known that virttally the whole western half of Tasmania was covered by an ice cap in Pleistocene 
time. U-shaped valleys, glacial lakes, moraines, striated pavements and erratic blocks - those unmistakable signs of an ice age are found throughout the West Coast. Although Gould must have passed close to the great outerop of the Mount Lyell ore body he did not discover it.

As the history and development of the West Coast mining fields is traced it will be noted that exploration parties almost invariably proceeded inland from Macquarie or Trial Harbour. Occasionally they made their way down from Burnie, via Mount Bischoff in the north. Seldom was the West Coast approached from the east. The deep and rugged valleys in themselves proved a formidable barrier to exploration but in addition an excessively high rainfall eaused the growth of dense rain forests that in many places still are literally impenetrable. The predominating species is the myrtle, Nothofagus cunninghami. The commercially important Tasmanian Blackwood, an acacia, and native Australian pines are also characteristic of the West Coast. However, the difficulty of access through these rain forests is caused by smaller trees, including the "horizontal scrub" and the "tanglefoot". These expressively named trees form an interlacing network of slender but tough springy branches. This, together with deposits of waterlogged vegetation which may accumulate to depth. of several feet, makes progress through these forests practically impossible.

Until the completion of the single track narrow gauge West Coast Railway in 1900 , the only means of communication between the East and West Coasts of Tasmania was by sea to Macquarie Harbour or Trial Harbour. The railway was built piecemeal. A private company built and still operates the line between Burnie and Zeehan. The Tasmanian Government built and still operates the line between Zeehan and Strahan, while the Mount Lyell Mining Company built and still operates the line between Queenstown and Strahan. It seems incredible that after one hundred and fifty years of settlement in Tasmania the road link between Burnie and Strahan still remains to be completed. The Lyell
Highway from Hobart to Queenstown, the one direct east-west route, was built only some twenty-five years ago. It will be realized that the term West Coast does not apply solely to the coast line but to the whole of Western Tasmania lying between the coast and the Central Plateau. The southern half, of course, is rough, mountainous, unsettled, and to this day largely unexplored.

To return to the story of the Mount Lyell field: In 1881, prospecting parties struck inland from Macquarie Harbour, and gold discoveries in the vicinity of where Queenstown now stands caused an influx of miners to the district. Many of them came from the declining Heemskirk tin fields and it was one of these parties (in 1884) that pegged out the area containing the "Iron Blow", the name given to the huge outcrop of the Mount Lyell ore body from which the alluvial gold of the district had been shed. It was worked for gold at first with unpromising results. After some initial mystification as to the nature of the ore body it was reeognized to be a prritic mass of vast size consisting of pyrite (iron sulphide) and smaller amounts of chalcopyrite (copper iron sulphide), the chief ore of copper. sufficient to yield a steadv 2 to 3 per cent. of the metal, together with smaller quantities of gold and silver and very little gangue.

Such huge pyritic ore bodies are famous historically because they could be mined by quarrying and the copper was easily extracted by crude metallurgical processes. The pyritic masses of Rio Tinto and Tharsis, in south-western Spain. were worked first in prehistoric time and then by the Phoenicians, from 1200 B.C. to 600 B.C., who made bronze by alloving the copper with Cornish tin. Many centuries later the deposits were re-worked by the Romans, who organized the industry on such a scale that a population of some millions gathered on the field.

In 1891 Melbourne metallurgists and financiers came to the decision to work Mount Lyell for copper, with gold and 


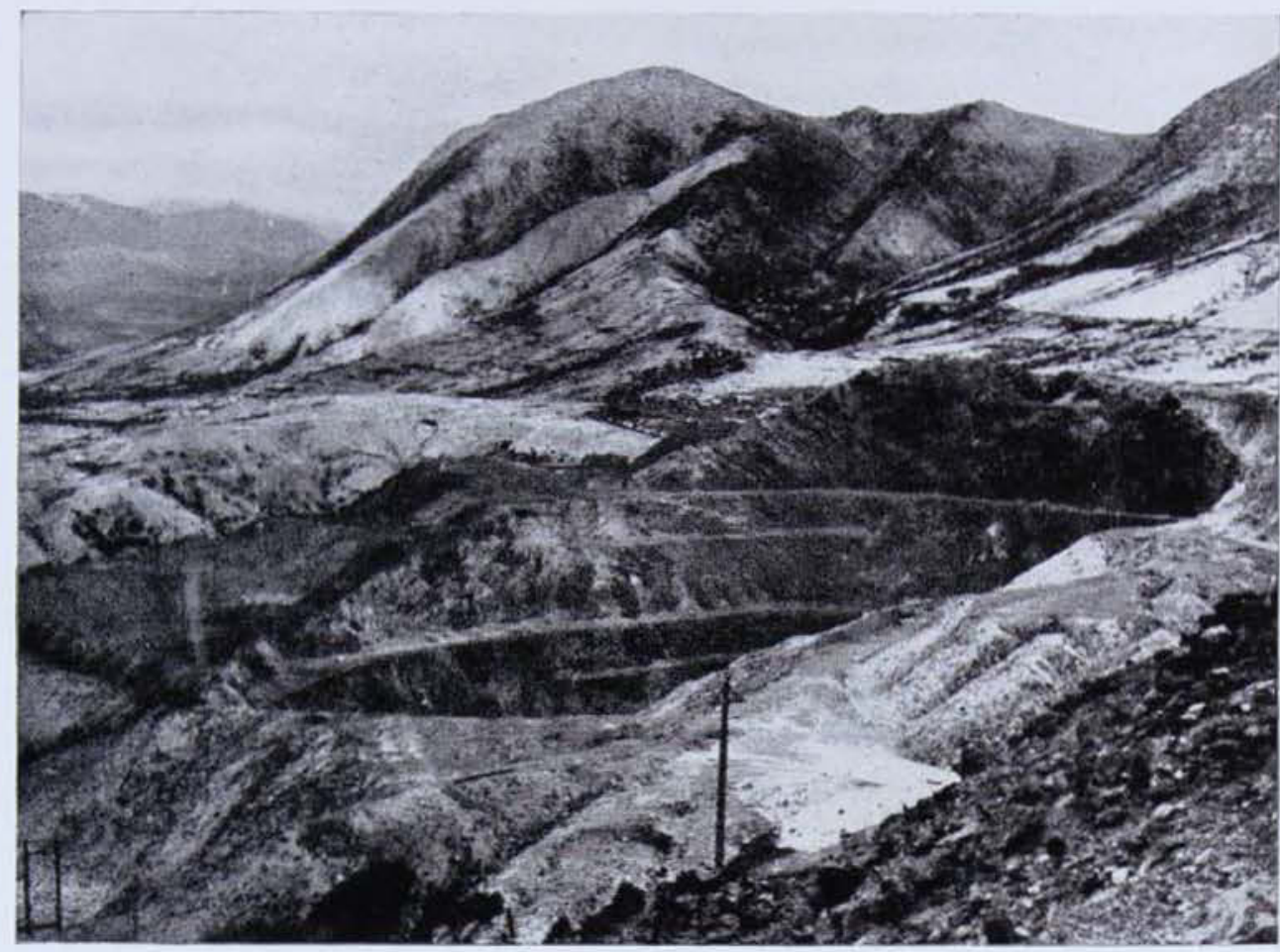

The worked-out "Iron

Blow" open cut.

Photo,-T. N. Mirfield. silver as by-products. Smelters and treatment plant were erected and the town of Queenstown came into existence. It is now Tasmania's fifth largest town, with a population of 4,000. By 1899 Queenstown was connected with Strahan by rail. Some thirty other companies had come into existence by 1900 , the only recommendation of most of them being their proximity to the Mount Lyell mine. The majority of these never paid a dividend and gradually all collapsed or were absorbed into the big company.

The Mount Lyell ore body occurs in an important formation of lavas and tuffs that have been metamorphosed to schistose types. These so-called Read-Rosebery volcanies underlie the West Coast Range Conglomerate. The field is situated on a ridge of schists connecting Mount Lyell with Mount Owen. On the eastern side of the ridge lies the Linda Valley and on the western side lies the town of Queenstown, on the Queen River, which is always turbid and grey because the waste from the treatment plant passes into it.

The ore body was first worked as an open cut. It was of huge dimensions, 650 feet long and 250 feet wide. When the openeut reached a depth of 450 feet, $4,000,000$ tons of ore having been removed, the ore body was worked by underground mining. With the depletion of ore in this and several other underground workings, in 1934 a new phase was entered. Hard siliceous schists carrying only 0.7 per cent. copper were worked by open-cut methods on the western side of the ridge. These are of very great extent and give rise to optimism concerning the future of the field.

The visitor to Queenstown, after he has recovered from the hair-raising descent of the Lyell Highway, is struck by the almost complete absence of vegetation on the slopes of Mount Owen, which towers most impressively above the town. In the early days all the ore, including both the pyrite and the chalcopyrite, went through the smelters and thirteen of them worked continuously to cope with the vast output. The continuous clouds of sulphur dioxide coupled with the 110 -inch rainfall must have meant that the whole place was continuously bathed in a weak solution of sulphurous acid and this, compled with the constant drain on timber for mining purposes, destroyed the original dense forest cover. For many years now the pyrite has been separated from the chalcopyrite. after crushing, by flotation methods and 


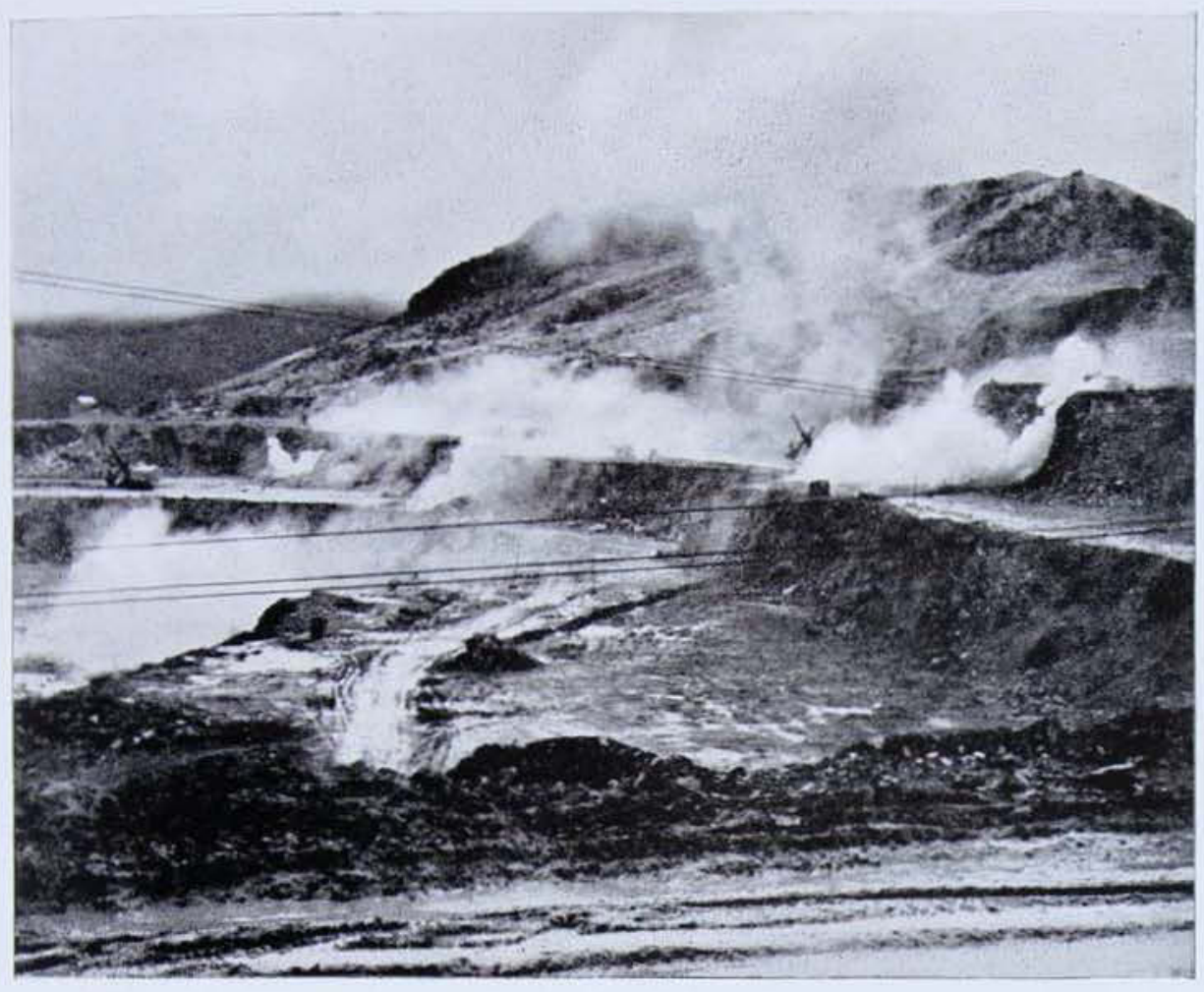

Blasting on the benches of the West Lyell open cut. Photo.-"Pix".

Mount Lyell Mining Company's treatment plant, smelter, and giant slag heap (the dark lake-like patch in the centre of the picture) on the foothills of Mount Owen. Queenstown lies to the right.

Aerial photo.-Brown and Durean.

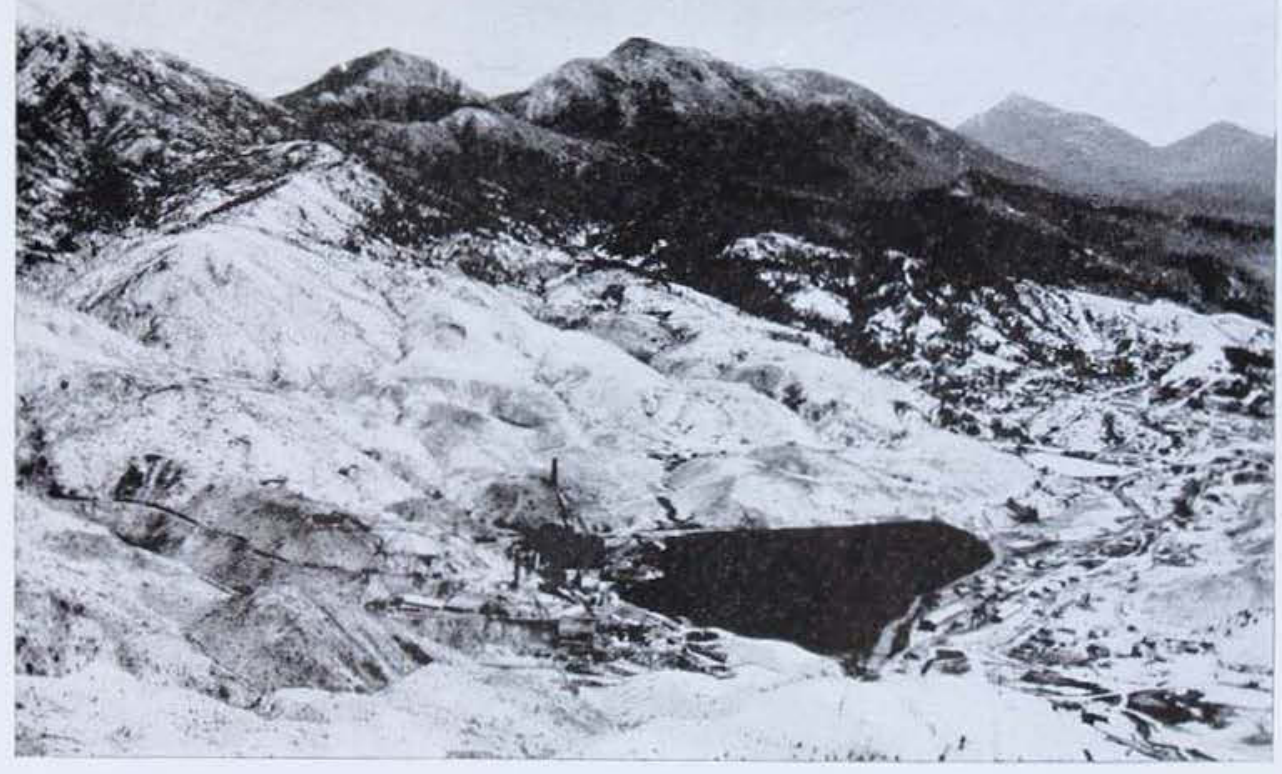

is sent straight to the mainland for sulphuric acid manufacture. Consequently only one smelter is now required and it does not need to work continuously. The company has its own hydro-electric station at Lake Margaret where all the isohyets on the West Coast seem to merge, giving it a really formidable 144 -inch rainfall. Because of the inexhaustible supply of electricity the company has its own electrolytic refining plant and Queenstown was an all- electric town in the days when electricity was not generally being used for cooking and heating.

Mount Lyell is not particularly noted for variety and choiceness of mineral specimens. However. I was fortunate enough to collect some quite massive lumps of chalcopyrite in the West Lyell open cut workings, which was unusual since the ore is mostly very finely disseminated and very low grade. Large specimens of black, 
lustrous micaceous haematite in the West Coast Range Conglomerate, adjoining the old Mount Lyell open cut, were also obtained. The Museum is fortunate in having a fine series of minerals from the North Lyell Mine which was situated about one mile north of the "Iron Blow" and was worked extensively by underground methods, but together with all other underground mines on the field has gradually ceased working as the ore reserves became depleted. The late A. D. Combe worked in the North Lyell mine many years ago and included in the collection he generously presented to the Museum in 1947 are specimens of beautifully crystallized chalcopyrite and massive bornite, a dark purple sulphide of copper and iron. popularly ealled "peacock ore" because of its iridescent colours.

\section{Insects of Captain Cook's Expedition Part I}

\section{By A. MUSGRAVE.}

$\mathrm{I}$ I the present article I propose to deal with the Australian insects taken on Captain Cook's First Expedition.

Captain James Cook, it will be remembered, led three expeditions to the Pacific. The first was carried out while he was Lieutenant James Cook in H.M.S. Endeavour, during 1768-1771. I have already touched upon this expedition in my Presidential Address to members of the Royal Zoological Society of New South Wales, ${ }^{2}$ and many of the facts embodied in that address must herein be recapitulated later. The second expedition took place in 1772-1775. Cook was in the Resolution and Tobias Furneaux was in command of the Adventure. This last-named vessel put in to Adventure Bay, Tasmania, in February, 1772, for five days, but this expedition does not here concern us. The third expedition took place during 1776 1780 ; Cook was in command in the Resolution and Charles Clerke in the Discovery. The Resolution put in to Adventure Bay, Tasmania, from 26-30th .January, 1777; insects are mentioned in Cook's Journal, and these were later named by Fabricius in his two-volume work, Mantissa Insectorum (1787). It was on this third expedi-

* The History of Australian Entomologieal Research, Australian Zoologist, Vol. vi, Pt. 3, August 20,1930 , pp. $189-203$. tion that Cook was killed by the natives of Kealeakakua Bay, Hawaiian Islands, on 14th February, 1779.

\section{The First Voyage.}

During the First Voyage Cook's vessel, H.M.S. Endeavour, homeward bound after her visit to Tahiti, where observations were made on the Transit of Venus, put in at Botany Bay on the east coast of New Hol. land on 29th April, 1770. Here at Botany Bay the naturalists of the parts. Joseph Banks and Dr. Carl Daniel Solander, made collections of plants and animals, and were so impressed by the luxuriant growth of the former that it was suggested that the bay be called Botanist's Bay, though this name was later changed to the "Botany Bay", of the present era. The names of the two famous collectors are commemorated by Cape Banks and Cape Solander, the headlands to the bay.

Probably only a few insects were col. lected at Botany Bay, as the Endearmit was here at the end of the second month of autumn when but few insects are about. No mention is made of the insects collected at Botany Bay in any of the works later published about the Expedition.

At least one species of insect collected by the Endeavour's party could only have been secured in these southern latitudes; 


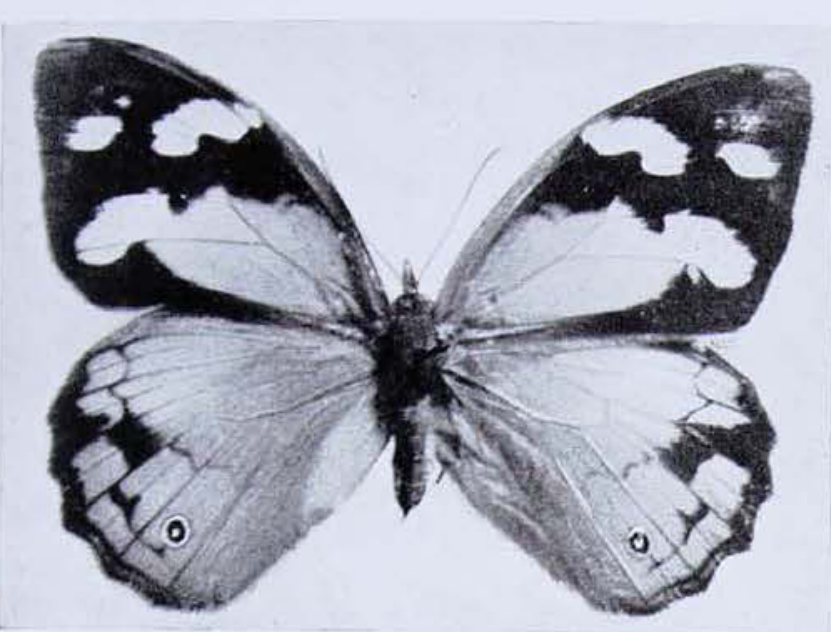

Female of the Common Brown, Heteronympha merope merope, a member of the family Satyridae, occurs commonly about Sydney. Females occur late in the season.

this is the female of the "common brown", Heteronympha merope merope (Fabricius, 1775, Papilio).

Another insect which could quite easily have been taken at Botany Bay was the Botany Bay Diamond Beetle, Chrysolophus spectabilis Fabricius, 1775, Curculio), a species which oceurs commonly about Sydney and Botany Bay on Acacias, and which was secured by the party in Eastern Australia.

After a week at Botany Bay the Endeavour left on 7th May to continue her journey northwards along the east coast of New Holland, as Australia then was termed.

On Wednesday, 23rd May, Cook and his party landed at Bustard Bay. Here they met with the nests of the Green Tree Ant, Ecophylla smaragdina virescens (Fabricius, 1775. Formica) in the branches of the mangroves. This is the first record we have of this interesting ant. Caterpillars, probably those of a "cup moth" of the family Limacodidae, were also met with, "every hair stinging much as nettles do", as Banks mentions in his Journal.

Further north again, at Thirsty Sound, parties landed on Tuesday and Wednesday the 29th and 30th May, and here both Banks and Sydney Parkinson (an artist to the Expedition) report meeting with "ants nests, made of clay, as big as a bushell", on the branches of the gumtrees.
These were termite arboreal nests made probably by Eutermes graveolus Hill or E. walkeri Hill, as I have seen nests similar to those described by Banks at Byfield, near Yeppoon, central coastal Queensland, on the trees there. The Green Tree Ant was again encountered at Thirsty Sound and is mentioned by Sydney Parkinson. Banks, too, records in his Journal, "In another species of tree, Xanthoxyloides mite, a small sort of black ant had bored all the twigs, and lived in quantities in the hollow part where the pith should be; the tree nevertheless flourishing and bearing leaves and flowers upon those very branches as freely and well as upon others that were sound.'

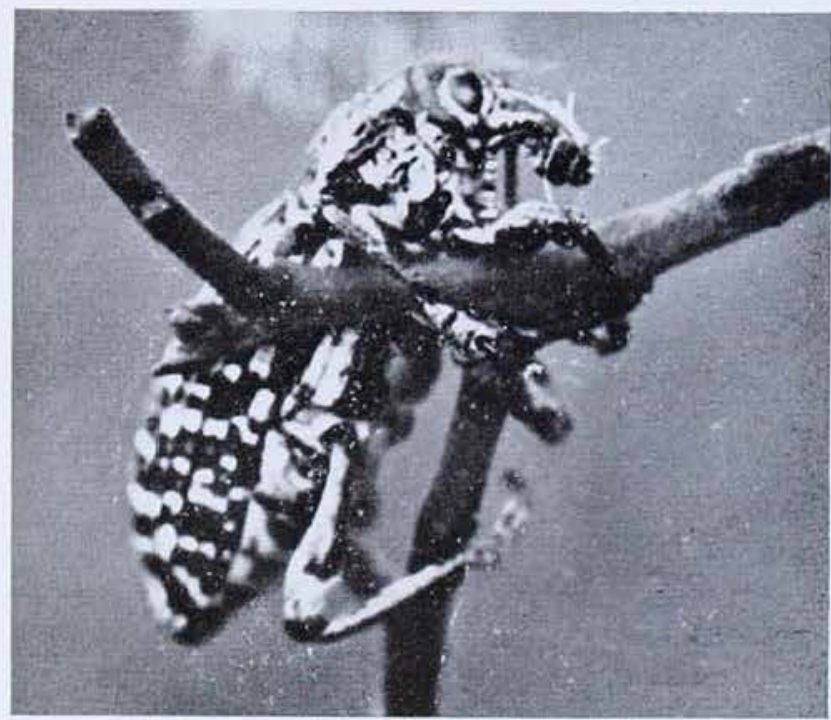

The Botany Bay Diamond Beetle, Chrysolophus spectabilis, a weevil found commonly on wattles about Port Jackson and Botany Bay. The specimen was photographed near Clifton Gardens, Sydney.

$$
\text { Phots:- luthor }
$$

At Thirsty Sound the butterflies attracted the attention of Banks, one species occurring in millions. This butterfly was evidently the well-known Blue Tiger. Danaus hamata Macleay, a species curiously enough not reported to be among the Banksian insect specimens, and therefore not recorded from the collection by the first deseriber-J. C. Fabricius. This insect was also seen at Cleveland Bay fortynine years later by Captain Phillip Parker King. who describes them as occurring in "incredible" numbers. The species ranges down the east Australian coast from Torres Strait to the Richmond River and occurs 


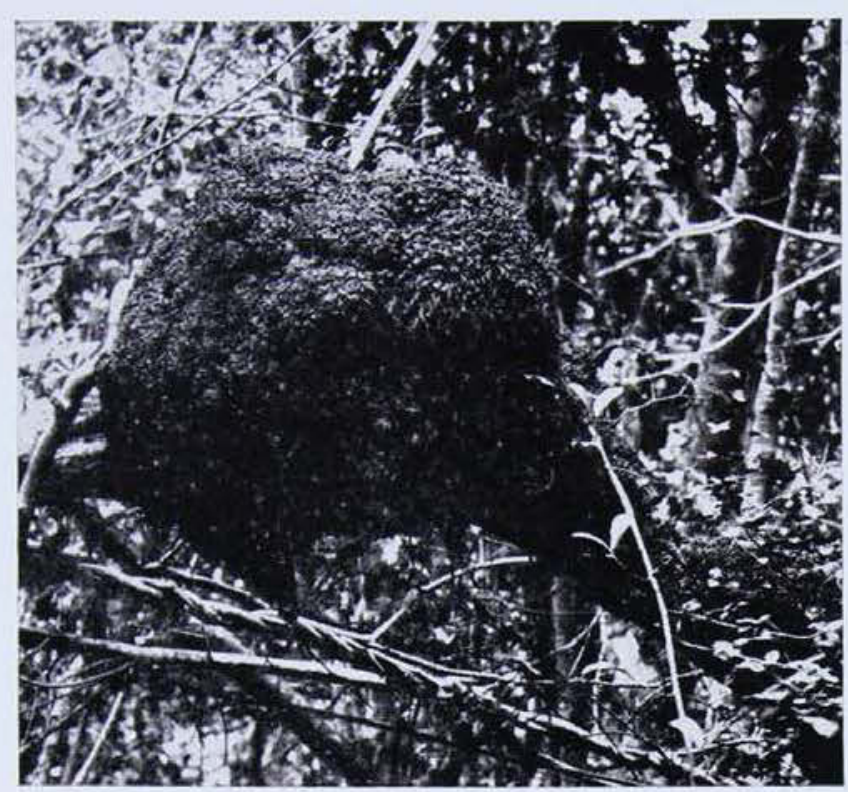

Arboreal termite nest at Yeppocn, Central Queensland. Photo.-Author.

also at Port Darwin. My colleague, Mr. F. A. MeNeill, has also recorded swarms of this insect on the Whitsunday Islands.

Banks reports finding "'a pupa or chrysalis which shone as brightly as if it had been silvered over with the most burnished silver, which it perfectly resembled". It emerged the following day and from his description we conclude that he had secured a specimen of the Common Australian Crow or Oleander Butterfly, Euploea core corinna Macleay, 1826, a species which, though among the Banksian material, did not receive its scientific name until fiftyone years later. This insect is very abundant about Sydney during the summer months in certain years, and has been called the Oleander butterfly because of its partiality to this plant while in the caterpillar state, though it feeds upon a variety of other plants with a milky sap.

Palm Island and Cape Grafton were next visited by the Expedition but we learn nothing of the insect fauna of these places.

Then, when off Cape Tribulation, the Endeavour grounded on a reef at night on 11th June, but through the efforts of Monkhouse, one of the midshipmen, they succeeded in fothering the ship. Monkhouse alone of the ship's company had previously seen this operation carried out. In about a quarter of an hour the ship was pumped dry.
On 17th June, 1770, Cook beached the Endeavour on the southern shore of the Endeavour River, and there, one hundred and three years later, a settlement was made and called Cooktown in memory of the great navigator.

The vessel was at the Endeavour River from 17th June until 4th August, 1770 , and, while the carpenters were repairing the ship, the scientists, Banks and Dr. Solander, collected natural history specimens in the surrounding district. It is highly probable that the majority of the insects collected by the Expedition were secured at the Endeavour River. Mr. T. G. Watkins has pointed out in his paper, Notes on the Butterflies of the Banks Collection, Entomologist, lvi, September, 1923 , pp. 204-209, that:

"As there had been no previous scientific voyage to New Holland and there was no subsequent return from one prior to the publication of the Systema, in 1775 , it may be assumed that all these types were obtained during the enforced sojourn at the future Cooktown in North Queens land in June to August, 1770".

\section{Accounts of the Voyage.}

After the Endeavour returned to England in 1771 several accounts were published about the Expedition. The official account was edited by John Hawkesworth, LL.D., and published in three volumes. ${ }^{2}$ In the third volume, chapter viii, we read "Departure from New South Wales; a particular Description of the Country, its Products, and People, etc.", 1773, pp. 627-630. Herein is given an account of the insects met with, such as the Green Tree Ant and the ants which live in the cavities of the epiphytic plants known as "ant plants". These ant plants are included in the genera

\footnotetext{
1 An Aceount of the Voyages undertaken by the order of his present Majesty for Making Discoveries in the Southern Hemisphere. And successively performed by Commodore Byron, Captain Wallis, Captain Carteret, and Captain Cook, In the Dolphin, the swallow, and the Endeavour: draun up From the Journals which were kept by the Several Communders, and from the Papers of Joseph Banks, Esq. By John Hawkesworth, LL.D. In Three Volumes, Hllustrated with Cuts, and a great Variety of Charts and Ifaps relative to Countries now first discovered, or hitherto but imperfectly known. 4to. London. Vol. iii, 1773. References to insects арреа on Pp. $520,529,627-630$.
} 


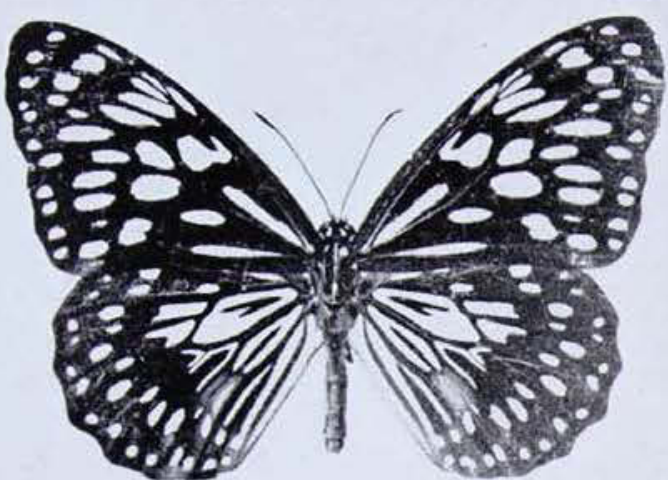

The Blue Tiger, Danaus hamata hamata, Macleay, occurs sometimes in vast numbers in certain localities in Queensland and adjacent coastal islands.

Photo.-Author.

Hydnophytum and Myrmecodia and contain cavities in their bulbous stems which are the homes of certain small brown ants of the genus Iridomyrmex. Iridomyrmex myrmecodiae Emery var. stewarti Forel is known from North Queensland. These ant plants may still be seen at Finch's Bay, Cooktown. White ants' (termites) nests are also mentioned. Termitaria also oceur about Cooktown.

The insects popularly referred to in Hawkesworth's account of the Voyage are taken from the MS. journal of Joseph Banks. It was not until 1896 that this Journal was published." Joseph Banks. naturalist, afterwards became Sir Joseph Banks and the President of the Royal Society in England. His Swedish associate in his collecting pursuits, and with whom his name is for ever linked, Dr. Daniel Charles Solander, a pupil of Linnaeus at Uppsala, afterwards helped Banks to name the large collections of plants secured on the Voyage, and in 1773 was appointed an under-librarian to the British Museum. Interesting biographical information about these two naturalists is given in J. H. Maiden's Sir Joseph Banks: The Father of Australia.

The year 1773 saw also the publication of another account of the Expedition. This was A Journal of a Voyage to the South Seas, in IIis Majesty's Ship. The Endeavour, by Sydney Parkinson, who was one of the artists on the Endeavour. He died after leaving Batavia on 27th January, 1771. The work was edited by his brother, Stanfield Parkinson. It contains the first reference to Australian sandflies, which he encountered at the Endeavour River, and he writes on p. 146, "We found also several sorts of snakes, ants, and a small culex, or fly, which is not bigger than a grain of sand; the bite or sting of which was venomous, and caused protuberances on the skin, which itched violently."

It is sad to reflect that of the Endeavour's company of ninety-five no less than thirty-eight died during the voyage, including six of the nine on Mr. Banks' staff

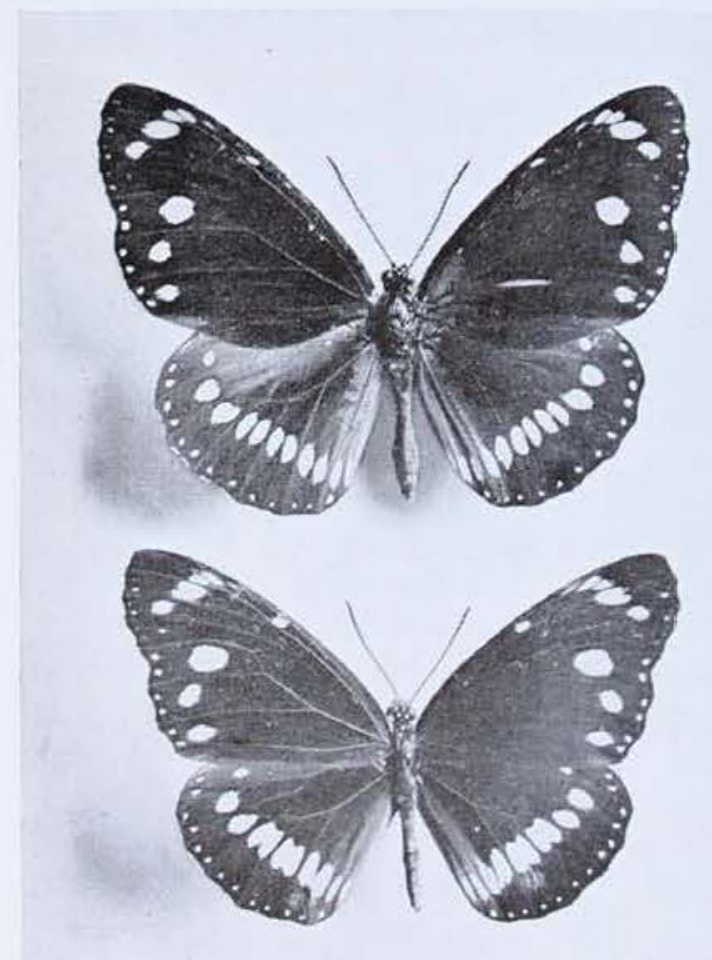

The Australian Crow or Oleander Butterfly, Euploea core corinna Macleay, is common in Eastern Australia in the warmer coastal regions.
In my Bibliography of Austratian Entomology, 1775.1980 (1932). pp. 12-14, I have, under the heading of "Sir Josep? Ranks", extracted all the references to insects observed by him in New Holland and recorded in his Journal edited by Sir Joseph D. Hooker. Under "Captain James Cook", op. cit. pip. $53-54$, will be found the places touched at by the Findeaveur on the east coa-t of New Holland and other iletails. 


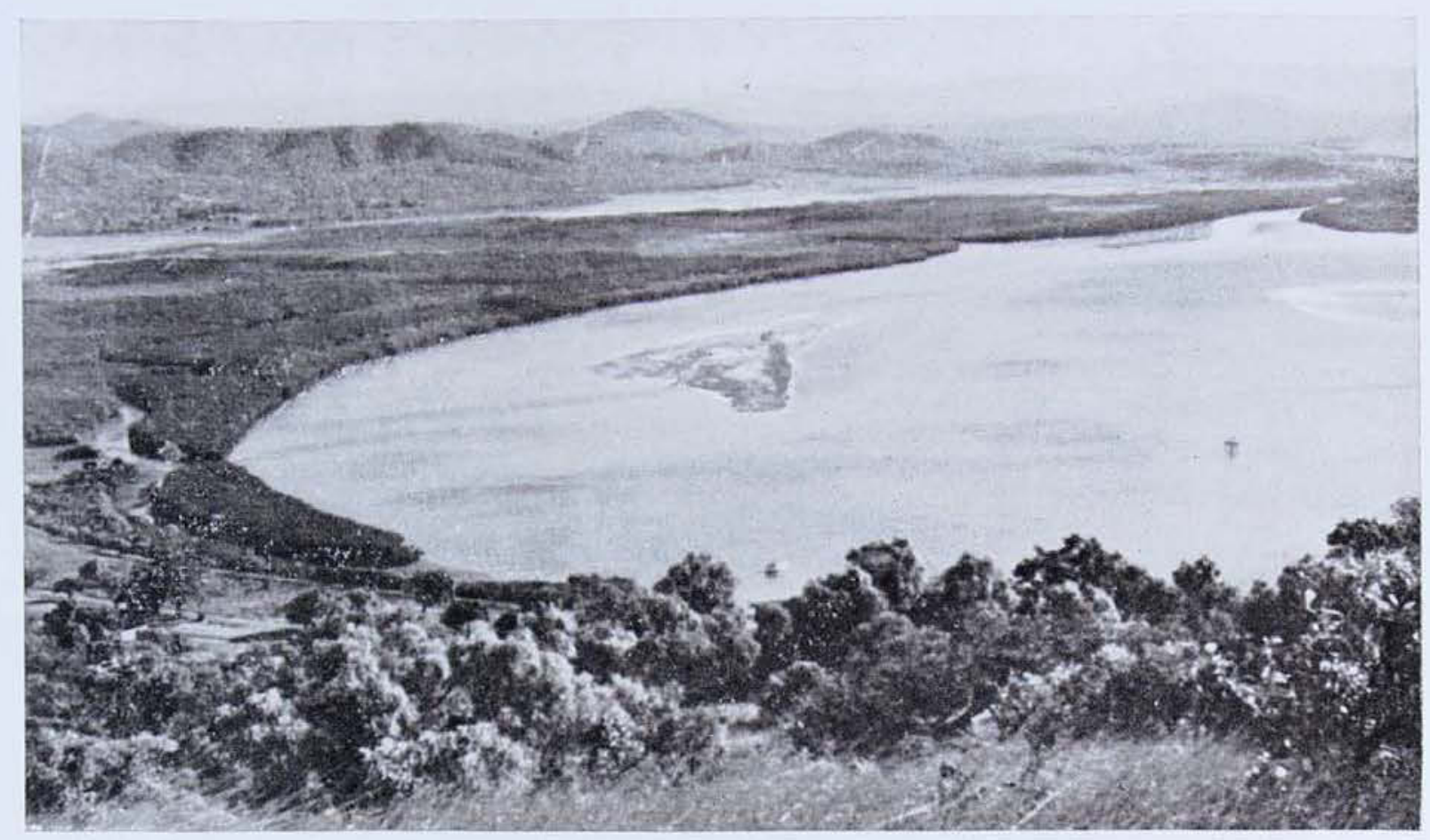

Estuary of the Endeavour River, from Grassy Hill. Mangroves line the southern shore as in Cook's day.

Photo.-Author.

and of which number three were the artists John Reynolds, Alexander Buchan and S. Parkinson.

\section{The Cooktown District.}

Before proceeding with a brief review of the various species of insects collected by the Expedition, it may perhaps be appropriate to consider first the environment on the Endeavour River where, we believe, the greater number of the insects were secured.

In 1873 the town of Cooktown was established on the south bank of the Endeavour River in anticipation of a gold rush to the Palmer River, some distance from the port. I have a personal interest in Cooktown as it is my birthplace, and it is fitting that I should here briefly allude to the town and the country surrounding it. In .June, 1951, I flew from Sydney and spent three weeks in Cooktown and the nearby district. I thought that by visiting the locality in June I would have the opportunity of securing many of the species of insects first secured by Cook's party.

The country about Cooktown consists of low hills with granite outcrops, and clothed with long grass interspersed with trees of no great height. Mt. Cook (1,414 ft.) lies south of the town, and Grassy Hill (570 ft.), lying to the east of the town, is the southern headland of the port. If we climb up Grassy Hill we are rewarded with a fine view of the town below us and we look up the estuary of the Endeavour River. This river consists of three branches, the South, North, and Right Branches, Mangroves still fringe the southern bank as they did in Cook's day.

The main street of Cooktown is Charlotte Street, which runs east and west, and where the shops are situated. And here is the Bank of New South Wales, the most imposing edifice in the town, and the three hotels: Sovereign, West Coast, and Commercial. In its heyday, Cooktown boasted about thirty hotels, but the Great Northern Hotel, once one of the finest hotels in the north, is in a state of utter disrepair due in part to the cyclone of 1949. Near where it is believed Cook repaired his ship we note the Cook memorial, unveiled in 1889, and in the same enclosure is a small obelisk to the ill-fated Kennedy expedition of 1848. On the way to the wharves we look across to the North Shore, Mt. Saunders, and Indian Head. 
About a mile south-east of the town is Finch Bay, the bathing beach of Cooktown, and Alligator Creek fringed with mangroves flows at the foot of Mt. Cook to enter Finch Bay and the Coral Sea. The beach here is covered with the pellets of the Sand Bubbler Crab, and sand dunes with ti-trees occur above the high-water mark.

Near the side of Mt. Cook is situated the home of the Olive family, well-known to naturalists, and from the grounds, filled with tropical plants of all kinds, we look back over Cooktown and the Endeavour River estuary.

Nearby is Keating's Gap and about four miles from Cooktown on the road to the tinfields, we come to Keating's Lagoon. Here I was able to collect many of the species of insects which were among those taken by Cook's party. By the side of the road we note many Poplar gums, Eucalyptus platyphylla, a speeies of eucalypt which was secured by Banks and Solander. It is interesting to note that some of the plants collected by Cook's party are in the Herbarium of the Sydney Botanic Gardens.

After the gold rush, which only lasted about five years, but during which about $5 \frac{1}{2}$ million pounds worth of gold, ehiefly alluvial, was secured, Cooktown gradually deteriorated, so that now only about three hundred people are resident there. These depend for their livelihood on tin mining. peanut growing and timber, though these industries are carried out at some distance

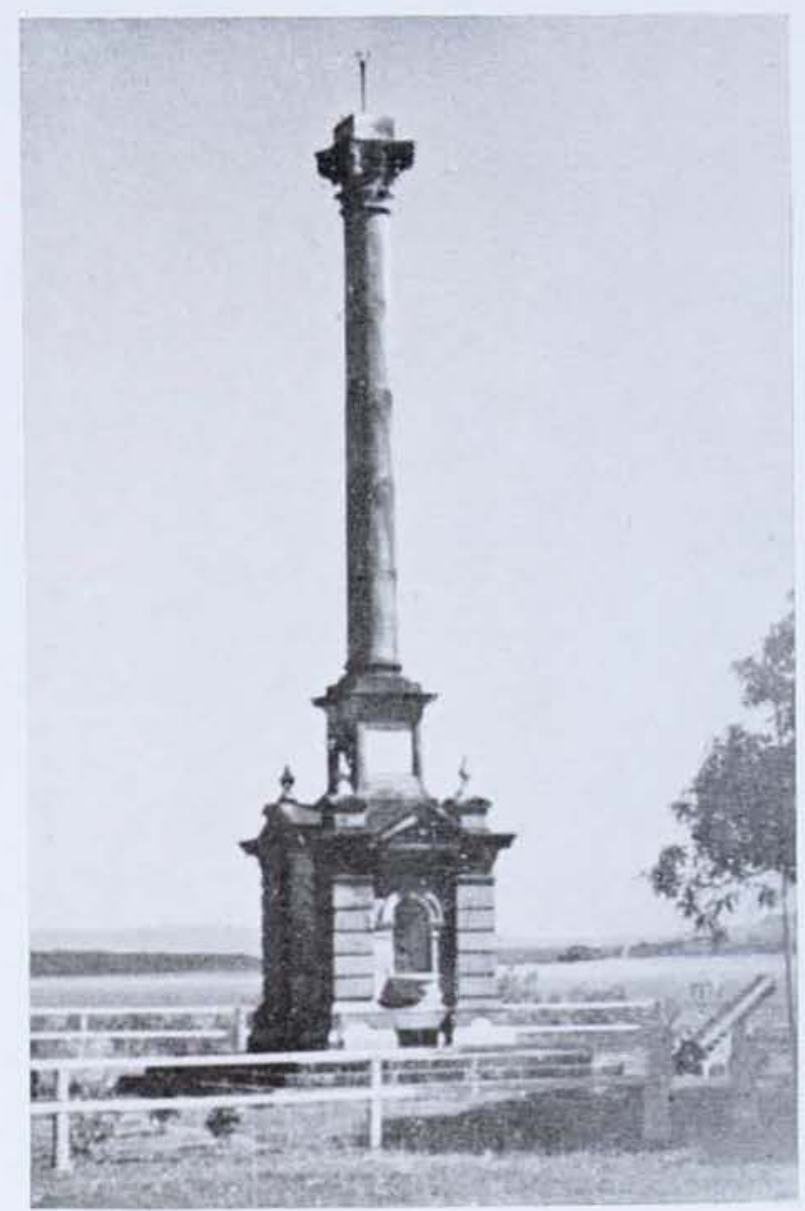

Cook's monument at Cooktown.

Ploto.-Author.

from the town; the mining south of Cooktown, the peanut growing north of the town on the McIvor River and at other places. There is a sawmill in Cooktown. Cooktown in the past has been flippantly termed "the town of the three G's-girls, goats and grog", though to-day this would scarcely app'y.

\section{BOOK REVIEWS}

Field Work in Antmal Brology. By Mary A. Besley and G. R. Meyer. Foreword by Prof. P. D. F. Murray. Illustrated. 68 pages. Angus and Robertson Ltd., Sydney-London, 1954. $7 \mathrm{~s} .6 \mathrm{~d}$.

The authors of this little book have shown foresight in providing a needed outline or introdue. tion to the science of ecology-the new and modern outlook to the study of natural history. The old order was primarily to observe and learn the identities of living things, but ecology has opened up far more interesting avenues of study. It provides explanations to the limitations of numbers, adaptations to environment and the many other fascinating facts concerned with living conditions in a crowded community.

The title of the work has, of necessity, to be technical, but technicalities are not over-emphasized in so far as the elementary instruetion to the 
student is concerned. The chapters cover the freshwater, the rocky ocean shoreline and the estuarine tidal flat habitats, and each is concluded with carefully selected references to relevant books and films which are easily accessible. A commendable afterthought was the inclusion of appendices giving broad general characters in the form of keys, by which the animals dealt with can be readily identified.

The booklet is a boon to young students and should be in the hands of every high school pupil taking the subject of biology for matriculation.

\section{-F. MoNEILL。}

Adam With Arrows: Inside New Guinea. By Colin Simpson, Angus \& Robertson, Sydney and London, 1953. 239 pp. 25 s.

This is a fine book, beautifully illustrated. It is written in a graphic, dynamic style which earries the reader into a world of primitive man in a jungle-covered environment, where the whirr of an arrow is like music in the ears of the warriors.

The book describes the intensely interesting exploits of field administration officers during their patrols into uncontrolled areas in central New Guinea. The author accompanied some of the patrols, and the tribute he pays to the fieldofficers, whose work he writes of so vividly, is one to a group of men in whom great courage and restraint are necessary in their dealings with natives who have not seen white men before and many of whom are still eannibals.

The book describes, in eighteen chapters, the history of the contact, with death lurking on every hand, of gold prospectors, miners, and field-officers, with a widespread group of natives called the Kukukuku-vicious mountain raiders hated and feared by all other native groups living in their vicinity. They are short-statured people who use the bow and arrow and stone-headed elub, and among whom cannibalism is still practised.

In the ehapter on eamnibalism an aceount is given of the smoking of the bodies of the dead. which are placed on rock-ledges on sacred mountains. There is a chapter on the life of the Kukukuku based on the field-work earried out among them twenty years ago by an Oxford anthropologist, Miss Beatrice Blackwood.

Other sections of the book deal with the pigmies in New Guinea, the human-hair wig-wearing people of Wabag, the outpost of Telefolmin and the initiation ordeal of the Mianmins. Throughout the book there are interesting accounts of the natives? fighting methods, magic, gardens, appearance, dress and ornament, dances and legends.
The colour-plates in Adam with Arrows are striking pictures of the natives described; they are supported by well-chosen reproductions of black-and-white photographs.

\section{-F. D. McCarthy.}

Marine Tropicals. By Edmond L. Fisher. Sub-Marine Studios, Miami, U.S.A. First edition, 1954 , pp. 1-56, illustrated.

This attractively preduced booklet is unusual in that it deals with the keeping of salt-water animals and plants in small home aquaria. It is beautifully illustrated from tropical American marine life observed by the author, a professional diver who is very keen on his hobby. His methods of earing for small fishes and invertebrates could be applied to Australian marine and shore life and thus commend themselves to our local aquarists, naturalists, frogmen and others, especially those residing near the Great Barrier Reef. Some of the eumbersome difficulties which used to daunt the salt-water aquarist are done away with by Mr. Fisher's more modern and tested methods, but experiments similar to those for keeping the American fishes would have to be tried under Australian conditions.

Some of the behaviour the author observed in his pets affords interesting reading and light mav be shed through the keeping of "marine tropicals" on some unexplained problems in biology, e.g., the revson for the remarkable colour-changes of Angelfish; the memories of fishes and how they ean be trained either by the aquarist or by a more "educated" fish : the "sleep bubble" exuded by the Bluehead, and other matters.

There is a short bibliography on marine life and an appendix in which scientific names are given to most of the species mentioned in the text. The proof's should have been more scrupulously checked to avoid the too numerous misprints and (allowing for differences between Ameriean and English usage) there are many mis-spellings; the singular and plural of such words as alga (algae) and ocellas (ocelli) seem to have been unknown to author, proofreader or editor. However, these lapses detract only in a small way from the enjoyment of an enthusiastic and helpful handbook which may well be a pioneer of its kind. It is especially pleasing to note that the author favours underwater conservation in a final plea that the shelters and breeding-places of fishes be left as undisturbed as possible. 